\title{
Bir Osmanlı Paşasının Padişahlık Rüyası: Sokulluzâde Hasan Paşa ve Resimli Dünya Tarihi
}

\author{
Tülün Değirmenci*
}

Sultanate Dream of an Ottoman Pasha: Sokulluzâde Hasan Paşa and His Illustrated World History

Abstract Illustrated histories were never merely products of simple literal activities at the Ottoman court. On the contrary, they functioned as political tools of the courtiers who commissioned the production of manuscripts, such as the sultan or viziers. The literary and visual images of the patrons appeared both in the texts and images of the manuscripts. In this article, focusing on an example of an illustrated history, I will examine the following questions: How was manuscript patronage used as a tool to enhance the patron's authority? What were the implications conveyed by the text and illustrations of the manuscript? And, how were manuscripts related to the political deeds of their patrons? In other words, I will discuss symbols of power in the early modern Ottoman culture in terms of visual and literal culture. At this point my example is an illustrated history prepared for Hasan Pasha the Sokulluzâde, the celebrated Ottoman vizier in Ottoman Baghdad. The two-volume manuscript is entitled Câmi üs-Siyer, literally "Collected Biographies" and housed at the Topkap1 Palace Library (H. 1369 and H. 1230). Taking an example of the Câmi ǘs-Siyer, I will explore the relationship between Hasan Pasha's ostentatious behaviors and political agendas. This examination allow us to understand the tools of being an Ottoman elite and its reflections in Ottoman material culture.

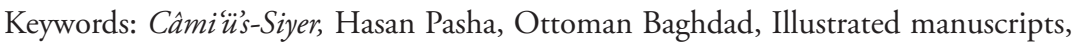
Ottoman material culture.

* Pamukkale Üniversitesi. Bu araştırma ARIT-Türk-Amerikan İlmi Araştırmalar Derneği’nin sağladığı katkı ile yapılmıştır; sağladıkları imkan için kendilerine teşekkür ederim. Çalışmanın sonuçları ilk olarak 16-18 Eylül 2015 tarihinde Napoli'de düzenlenen 15. Türk Sanatları Kongresi'nde sunulmuştur. Bu çalışmanın makaleye dönüşmesi ise Seyfi Kenan ve Erkan Tural'ın yardımlarıyla mümkün olmuştur; her ikisine de içten teşekkürlerimi sunarım. 
Bir Osmanlı devlet adamı temsil ettiği mevkii, sahip olduğu politik gücü kültürel alanda nasıl görünür kılardı? Ya da Osmanlı yönetici sınıfına dahil olmanın kültürel gereklilikleri ve de bu gerekliliklerin maddi kültür alanındaki yansımaları nelerdi? Osmanlı elitleri içinde bulundukları siyasi hizipler, hamilik ilişkileri kapsamında örtük bir şekilde saraya ve de daha açık bir şekilde siyasi rakiplerine karşı kamusal imgesini oluştururken ne tür araçlar kullanıyordu? Bu yazıda, bu soruları tartışmak üzere Osmanlı vezirlerinin en kudretlisinin, aynı zamanda da Sultan II. Selim'in (sal. 1566-1574) damadı Sokullu Mehmed Paşa’nın (öl. 1579) oğlu olan ve 16. yüzyılın ikinci yarısından 17. yüzyılın başına dek Osmanlı bürokrasisinde çeşitli görevler üstlenen Sokulluzâde Hasan Paşa’nın (öl. 1602) kültürel hamiliği, siyasi iddialarının ve ideallerinin, hatta hayallerinin bir aracı olarak kullanması; daha geniş bir bağlamda ise erken modern dönem Osmanlı siyasasında bürokratların güçlerini sunmak üzere kullandıkları araçların niteliği ve işlevselliği tartışılacaktır. Bu tartışma bir yandan Osmanlı siyasetinin 'değişim' ve 'kriz' dönemi olarak adlandırılan bir evresinde ${ }^{1}$ bir Osmanlı bürokratının siyasi emelleriyle şekillenen renkli kamusal imgesini yakından tanımamızı sağlarken, diğer yandan da bu imgenin yarattığı siyasi gerilimlerden devrin politikalarına, himaye biçimlerine dair bazı gözlemler yapmayı mümkün kılacaktır.

Kanuni Sultan Süleyman'ın (sal. 1520-1566) uzun süren saltanatının sonlarından itibaren Osmanlı saray siyasetinde devşirme kökenli vezirlerin her alanda güçlerinin doruğuna eriştiği, hatta bu gücün sultanın biricik otoritesini pek çok alanda sınırlamaya başladığı, son yıllardaki Osmanlı tarihçiliğinde geniş bir perspektifle tartışılan konulardan biridir. Ufuk açıcı nitelikteki bu çalışmaların bulgularına göre, Osmanlı saray siyasetinde vezirlerin lehine değişen bu yeni güç dengesinde, devşirme sistemi içindeki vezirler birbirlerini kollayarak çok çeşitli intisap ağları ve hiziplerin oluşmasına neden olmuştur. Güçlenen vezir sınıfı bir yandan sultanın gücünü paylaşarak imparatorluğu yönetirken diğer yandan da birbirleriyle iktidar yarışını sürdürmeyi ihmal etmemiştir. Vezirlerin güçlenen konumu, 16. yüzyılın ikinci yarısına hem siyasi hem de kültürel anlamda damgasını vuran Sokullu Mehmed Paşa’nın Osmanlı saray siyasetinde oynadı̆̆ı rolle adeta simgeleşmiştir ve aynı şekilde 'vezirlerin düşüşü' diyebileceğimiz süreç de Sokullu Mehmed Paşa'nın III. Murad devrindeki (sal. 1574-95) trajik sonu ile başlamıştır. 17. yüzyıl Osmanlı tarihçilerinden Peçevî İbrahim Efendi’nin

1 Bu tartışmaların kapsamlı bir değerlendirmesi için bkz. Günhan Börekçi, "Factions and Favorites at the Courts of Sultan Ahmed I (r. 1603-17) and his Immediate Predecessors", (doktora tezi), Ohio State University, 2010, s. 1-24. 
naklettiklerine göre, babasının vefatı üzerine Manisa'daki sancak görevinden son derece yorucu geçen bir yolculuk sonucunda İstanbul'a dönen III. Murad, bir anlık gafletle kendisini karşılayan Sokullu Mehmed Paşa’nın elini öpmeye yeltenmiş; Sokullu'nun ustaca manevrası ile bu olay gerçekleşmeden kendisi Sultan'ın elini öpmüştür. Bu hadise daha sonra yaşanan süreçte ne denli etkili olmuştur bilinmez ama, III. Murad, Sokullu'nun saray siyasetindeki kudretinden epeyce rahatsız olmuş, onun gücünü kırarak sultanın otoritesini yeniden güçlendiren bir siyaset gütmüştür. III. Murad'ın sultanlık kurumunu güçlendirmede işbirliği yaptığı yeni iktidar ortakları ise, bu sefer sarayın Harem bölümünden sorumlu olan ve çoğunlukla Habeşî kökenliler arasından seçilen darüssaade ağalarıdır. ${ }^{2}$ III. Murad'ın ardılı Sultan III. Mehmed'in saltanat yıllarında da (1595-1603) saray sahnesinde etkin rol oynayan farklı hiziplerin çekişmesi, yeni gelişen siyasi ve sosyal olaylara göre yeni biçimler alarak devam etmiştir. Bu dönemi ayrıntılı bir şekilde tartışan Günhan Börekçi, uzun süren Habsburg savaşları ve Anadolu’daki Celali isyanlarıyla gelişen askeri ve ekonomik krizin nedenini de saray çevresindeki hiziplerin mücadelesinde arar ve bu dönemde ortaya çıkan sekban isyanlarını hükümdar ile ordusu arasındaki anlaşmazlıktan ziyade saray sahnesindeki geniş katılımlı aktörlerin çıkar çatışması olarak görür. Bahsi geçen bu

2 Bu tartışmaların detayı için bkz. Baki Tezcan, The Second Ottoman Empire: Political and Social Transformation in the Early Modern World, (New York: Cambridge University Press, 2010); Metin Kunt, Sultan's Servants: The Transformation of Ottoman Provincial Government, 1550-1650, (Colombia: Colombia University Press, 1983). Baki Tezcan araştırmalarıyla hizipler arasındaki mücadelelerin rejimin şeklini dönüşüme uğrattığını göstererek dönemi "ikinci imparatorluk" olarak adlandırmıştır. Bürokratik yapıdaki ağları inceleyen diğer çalışmalar için bkz. Baki Tezcan, "Lost in Historiography: An Essay on the Reasons for the Absence of a History of Limited Government in the Early Modern Ottoman Empire," Middle Eastern Studies, 45/3 (2009), s. 477; Cornell H. Fleischer, Bureaucrat and Intellectual in the Ottoman Empire: The Historian Mustafa Ali (1541-1600), (Princeton: Princeton University Press, 1986); Leslie Peirce, The Imperial Harem: Women and Sovereignty in the Ottoman Empire, (Oxford: Oxford University Press, 1993). Jane Hathaway, The Politics of Households in Ottoman Egypt: The Rise of the Qazdağlis (New York: Cambridge University Press, 1997); a.g.y. A Tale of Two Factions: Myth, Memory, and Identity in Ottoman Egypt and Yemen (Albany, NY: State University of New York, 2003); Emine Fetvac1, Sarayın İmgeleri, Osmanlı Sarayının Gözüyle Resimli Tarih, çev. Nurettin Elhüseyni, (İstanbul, Yapı Kredi Yayınları, 2013); Giancarlo Casale, The Ottoman Age of Exploration, (New York and Oxford: Oxford University Press, 2010). Dönemin maruf bürokratlarından Koca Sinan Paşa’nın veziriazamlığını hizipler üzerinden anlamlandıran diğer çalışmalar için bkz. Ahmet Önal, "Koca Sinan Paşa’nın Hayatı ve Siyasi Faaliyetleri 1520-1596” (doktora tezi), Marmara Üniversitesi, 2012, s. XII-XII; 70-77; Elif Özgen, "Grand Vizier Koca Sinan Paha and Factional Politics in the Court of Murad III” (yüksek lisans tezi), Bilgi Üniversitesi, 2010. 
aktörlerin arasında hanedanın kadın üyeleri, ulema mensupları, vezirler, ağalar gibi çok farklı kesimler vardır. ${ }^{3}$

Siyasi sahnedeki sultan ve onu çevreleyen farklı gruplar arasındaki bu katmanlı ve karmaşık güç ağları kuşkusuz kültürel alanda da girift hami-mahmi ilişkileri ile şekillenen bir ortama sebep olmuştur. 16. yüzyılın ikinci yarısında güçlenen vezir sınıfının adeta temsilcisi olan Sokullu Mehmed Paşa, söz gelimi, siyasi alandaki kudretine paralel olarak önemli bir sanat hamisidir. Sokullu Mehmed Paşa'nın sanat alanındaki patronajına baktığımızda kariyerinin başından sonuna değin dönemin politik şartlarına göre oluşan ve yeniden şekillenen bir seyir izlediği gözlemlenir. Bir başka deyişle, Paşa için hazırlanan her resimli elyazması ile bir yandan Sadrazamın rolü tanımlanırken bir yandan da Sultan'ın konumu yeniden çizilmiştir. Sokullu Mehmed Paşa’nın politik gücünün yansıdığı en önemli eserlerin başında 1569 tarihli Kanuni Sultan Süleyman'ın son seferini, Sultan II. Selim’in tahta çıkışını ve saltanatının ilk yılını anlatan Nüzhet-i esrârüll-ahyâr der-ahbâr-ı sefer-i Sigetvar gelmektedir. ${ }^{4}$ Sokullu Mehmed Paşa’nın hizmetindeki Feridun Ahmed Bey tarafindan yazılan bu elyazmasında Sokullu Mehmed Paşa'nın Zigetvar seferi sırasındaki hayati rolü ve de Kanuni'nin vefatının ardından II. Selim'in sorunsuz bir şekilde tahta çıkmasını sağlayan kişi olarak temsili öne çıkar. Sokullu Mehmed Paşa’nın III. Murad için hazırlattığı ya da hazırlanmasına katkı sağladığı resimli el yazmalarında ise Sadrazam olarak daha geri plana çekildiği, Sultan'ın ise bütün bürokrasinin gerisinde ama en yükseğinde duran bir konuma yerleştirildiği dikkat çeker ki, kuşkusuz farklılaşan bu ikonografi Sokullu'nun III. Murad devrinde değişen siyasi konumunun bir tezahürüdür. $^{5}$

Sokullu'nun hem Osmanlı siyasetinde oynadığı rol hem de bir sanat hamisi olarak yaptıkları kuşkusuz ki oğlu Hasan Paşa’yı etkilemiş olmalıydı. Nitekim Sokulluzâde Hasan Paşa’nın Osmanlı bürokrasindeki günleri de tüm bu sürece denk geliyordu; 1560 'larda başladığı inişlerle ve çıkışlarla 1602'ye kadar devam eden bürokrasi kariyeri aynı zamanda babası Sokullu Mehmed Paşa’nın Osmanlı siyasetindeki hem en parlak günlerine hem de gözden düşme sürecine şahitlik

3 Günhan Börekçi, "Factions and Favorites", s. 70-76.

4 Elyazmasının metni yakın zamanda yayımlanmıștır: Feridun, Nüzhet-i Esrârüll-Ahyâr Der-Ahbâr-ı Sefer-i Sigetvar: Sultan Süleymanin Son Seferi, haz. A. Arslantürk, Günhan Börekçi, Abdülkadir Özcan (İstanbul: Zeytinburnu Belediyesi, 2012).

5 Fetvac1, Sarayın Imgeleri, s. 143-193. 
etmişti. 1561'de Bosna beylerbeyi olan Hasan Paşa ardından Diyarbakır, Şam ve Halep, Anadolu ve Rumeli beylerbeyi olarak görev yapmış; Ferhad Paşa’nın Gürcistan seferinde çeşitli görevlerde bulunmuştur. 1593'te vezaretle Budin beylerbeyi olan Hasan Paşa’nın 1596'da III. Mehmed'in Eğri Seferi’ne katıldığı bilinir. 1597 'de İstanbul'a çağrılmış; bu sırada veziriazamlık beklemiş ancak bu isteğine ulaşamamıştır. 1598'de kendisine tevcih edilen Bağdat valiliğgi görevini istemeyerek kabul etmek zorunda kalmıştır. ${ }^{6}$ Nitekim dönem tarihçisi Selânikînnin ifadelerinden de anlaşılacağı üzere padişahın emrine de karşı gelme şansı pek kalmamıştır:

Kapucılar Kethüdâsı Abdullah Ağa debdebe ile varup, 'Fermân-ı Pâdişâhî Bağdad'a gitmekdür, emre imtisâl idersenüz febihâve ni'me ve illâ Yedi-kulle’ye iletmek buyruldı' dimekle 'Ferman Pâdişâhundur' gidelüm diyüp Bağdad seferi tedârükine başlayup Dîvâna gelmez oldılar. ${ }^{7}$

Bağdat dönüşünde Celalilerle girdiği mücadelede, 1602 yılında Tokat Kalesi'nde öldürülmüştür. Osmanlı kaynaklarında anlatılanlara göre bu olay şöyle gelişmiştir: Celali lideri Karayazıcı'nın yerine geçen kardeşi Deli Hasan önderliğindeki Celaliler 1602 ilkbaharında Halep'e yönelmek niyetiyle Amasya ve Tokat üzerine yürümüşler; bu arada da yol üzerindeki yerleşimleri yakıp yıkmışlar, üzerlerine gönderilen Osmanlı paşalarını bertaraf etmişlerdir ki bunlardan biri de Hasan Paşa'dır. Celali birlikleri karşısında yenilen Hasan Paşa askerleri ile birlikte Tokat Kalesi'ne çekilmiş ancak hazinesi Deli Hasan'ın eline geçmiştir. Deli Hasan ve eşkıyası Paşa’nın hazinesindeki beş milyon altın, çok sayıda çadır ve Paşa’nın haremindeki dört yaşlı kadın dışındaki her şeye el koymuşlardır. Tüm kenti kuşatmalarına rağmen Hasan Paşa sığındığı kaleden çıkmadığı için onu öldürmeyi bir türlü başaramamışlardır. En sonunda her gün belirli bir yerde oturma alışkanlığını öğrenerek keskin bir nişancıya kendisini vurdurmuşlardır. ${ }^{8}$

6 Erhan Afyoncu, "Sokulluzade Hasan Paşa”, Türkiye Diyanet Vakfi İslâm Ansiklopedisi, 2006, 37, 366-368.

7 Selânikî Mustafa Efendi, Tarih-i Selânikî (971-1003/1563-1595), I-II, haz. Mehmet İpşirli (Ankara: Türk Tarih Kurumu Yayınları, 1999), s. 722-723.

8 William J. Griswold, Anadolu'da Büyük İsyan, 1591-1611, çev. Ülkü Tansel (İstanbul: Tarih Vakfı Yurt Yayınlar1, 2002), s. 31-32. 
Son görevi olan 1598'deki Bağdat valiliğine atanmadan hemen önce İstanbul'da bir süre sadrazamlık ümidiyle beklemesine rağmen bu isteğine kavuşamaması; hatta hiç istemediği bu göreve bir nevi sürgün olarak gönderilmesi Hasan Paşa'nın bu dönemde saray çevrelerinde çok makbul görülmediğini gösteriyor. Olasılıkla bu gözden düşmede babasının himayesinden mahrum kalmasının da payı vardı. Oysa Bağdat valiliği Hasan Paşa’nın bir Osmanlı bürokratı olarak kamusal imgesini oluşturmada, belki de babasından gördüğü himaye ilişkilerini gerçekleştirebileceği eşsiz bir imkan sunacaktı.

\section{Gücün Sunumu: Görkem ve Gösteriş}

Sokulluzâde Hasan Paşa’nın kamusal görünürlüğünün Osmanlılarca algılanma biçimini, 17. yüzyılın hemen başında hazırlanan bir resimli elyazmasındaki suretinden 'okumak' mümkündür. Bu tasvir, bir başka Osmanlı bürokratı ve de aynı zamanda şairi olan Ganizâde Nâdirî̀nin Dîvân'ında (TSMK. H. 889) yer alır. Sultan III. Mehmed'in Eğri Seferi sırasında gerçekleşen Haçova Savaşı'nı (1596) betimleyen sahne, Osmanlı savaş tarihinin ilginç anlarından birini bütün detayları ve canlılı̆̆ ile aktarır. Son anda yenilgiden zafere dönüşen savaşa katılan Osmanlı paşalarının birlikleri, bu resimde tüm detayları ile betimlenir. Her bir paşanın isimlerinin yazılı olduğu sancaklar onları rahatlıkla tanımamızı sağlar. Bunlardan biri de sağ taraftaki sayfanın hemen ortasında yer alan ve Rumeli askerine komuta eden Sokulluzâde Hasan Paşådır (Resim 1). Tasvirde, koyu renk sakalı ve yuvarlak yüz çehresi ile henüz genç bir yaşta olduğu belli olan Hasan Paşa yeşil renkli bir kaftan giyinmiştir. ${ }^{9}$ Rumeli askeri ile ordunun sağ kanadını tutan Hasan Paşa anlaşılan o ki bu muharebede askeri performansından daha çok, görkemli dış görünüşü ile konuşulmuştur. Nitekim Haçova Savaşı'nın en canlı betimlemelerinden birini yapan 17. yüzyıl tarihçisi Peçevî Efendi, Hasan Paşàyı Eğri metrisinde pek çok defa gördüğünü; kendine has bir kıyafet olarak kırmızı atlas entari üzerine altın işlemeli Anka kuşu tasvirli bir kuşak bağladığını söyler. ${ }^{10}$

Peçevînnin ifadeleri, Hasan Paşa’nın savaş sırasında bu kadar gösterişli kıyafetler içinde olmasını biraz yadırgadığını düşündürür. Hasan Paşa’nın kendine özgü kıyafet ve davranış biçimleri sadece Eğri Seferi'nde dikkat çekmez.

9 Dîvân-ı Nâdirî, TSMK, H. 889, y. 6b-7a. Resim hakkında bilgi için bkz. Tülün Değirmenci, İktidar Oyunları ve Resimli Kitaplar: II. Osman Devrinde Değişen Güç Simgeleri, (İstanbul: Kitap Yayınevi, 2012), s. 156-159.

10 Peçevî, Tầrîh-i Peçevî, II, (Matbaa-i Amire, 1283), s. 30. 
TÜLÜN DEĞİRMENCİ

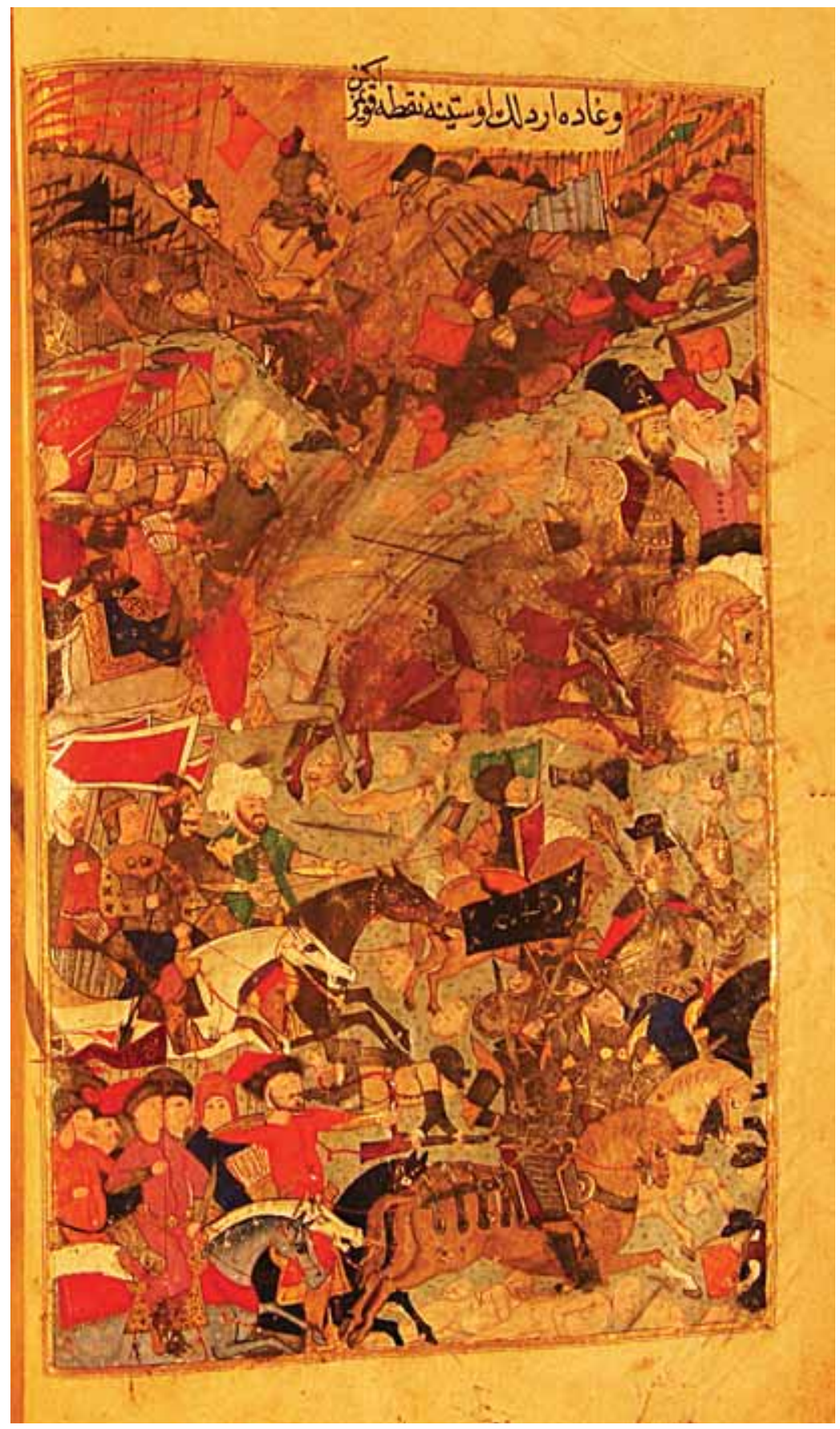

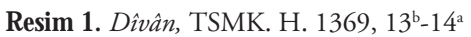


Nitekim Peçevî anlatımında Hasan Paşa’nın garip işleri hakkında pek çok detay verir. Tarihçinin anlattıklarına göre, Hasan Paşa Bağdat valiliği sırasında (15981602) padişahlar gibi gösterişli davranışlar içinde Cuma namazına çıkarmış. Hatta, babası Sokullu Mehmed Paşa durumu öğrenince padişah öğrenir de başına iş gelir diye endişelenerek oğlunun bu görevden azledilmesini Sultan'dan istemiş; ancak durumdan haberdar olan Sultan, azledilmesin ama böyle çalım satmaktan vazgeçsin diyerek Paşa'nın uyarılmasını emretmiştir. Peçevî anlatımın devamında, Hasan Paşa’yı bir yandan çelebî diğer yandan da mă̆rur, hod-bîn ve hod-pesend (her ikisi de bencil, mağrur anlamında) olarak tanımlayarak değil akranlarına, kendinden üstün olanlara bile iltifat göstermediğini söylemektedir. Hasan Paşa'nın garip davranışlarından biri olarak sevdiği bir genci yanına hazinedar olarak atadığını, bu gence kendi kıyafetinin aynısını giydirerek sürekli yanında gezdirdiğini de anlatmaktadır. Tüm bunlar arasında Hasan Paşa’nın en acayip işi ise, Bağdat valisi iken yaptırdığı gümüşten tahtıdır. Kâh-ı Behişt yani Cennet Köşkü adını verdiği bu tahtın üzerinde ham gümüşten ağaç, yaprak, bahar, turunç ve nar gibi meyvelerden süsler vardı ki göreni hayran bırakırdı. Hatta Bağdat dönüşü Celaliler tarafından yağmalanan hazinesi içinde bu taht özellikle dikkati çekmiş, Celali eşkıyasından Deli Hasan bu tahtı kurdurarak adamlarına seyrettirmiştir:

"Babası hayâtında ve ba'dehû öte yakanın ekser eyâletlerine vâlî olmuş idi. Hatta nakl olunur ki, Bağdâd'da vâlî iken pâdişâhâne tavır ve tarz ile Cum'aya çıarmış. Babasına mün'akis oldukda mebâdâ pâdişâha nakl olunursa sebeb-i gayz-1 pâdişâhî ola şâkîleri vardır deyu 'azlin 'arz ider. Sa âdetlü pâdişâh yok 'azl olunmasun amma değme/dikme yapukları kaldırsun deyu tenbîh ile buyururlar. Meğer cenâb-1 hazret-i pâdişâha kendiden mukaddem işitdirmişler imiş. Gâyet vecih-i nümâyişi bî-mânend bir şehbâz ve şehlevend çelebî idi. Amma bir mertebe mağrûr ve hod-bîn ve hod-pesend idi ki katâ gözüne kimesneyi kestirmez idi. Akrânı olandan kat'i nazar, mâ-fevkine dahî iltifât itmez idi. Ve bir vaz'ı bü'l-âcebî var idi ki, âshâb-1 devletten birinden görmek ve işitmek vâki' olmamışdır. Meselâ bir gulâma meftûn ve hevâdâr olub hazinedâr iderdi ve kendi giydigi libâs ile telbîs ve bindiği at misâli bir ata süvâr ve cümle raht-1 besâtı hemvâr ve başlarında birer Selimî destâr alâyda bu kadar ûmerâ ve kibâr var iken birin yanaşdırmaz ve ilâ-evvel gulâm ile hem-rikâb ve hem-'inân olub gider idi. Meğer alây selâmında gulâm atının başını kendi rikâbı beraberine çeker idi. Eğer Rumili'nde eğer Anatolu'da âdeti böyle idi. Ve yine kendi otağına hem-tınâb bir mükemmel otak kurulub mülâkâta gelen sagîr ve kebîr ve mîrmîrân ve emîr-i kethüdâdan sonra hazinedâra ba'dehû kendiye mülâkât 
ider idi. Ve ağalarından hazinedârlığından çıkma iken kapucubaşısı dahî kendinin giydiği eğer atlas-i kemhâ ve eğer serâser-i dîbâ her ne ise anlar dahî anı giyüb her kande gitse der pey giderlerdi. Divân etse dahi mukâbelesinde tururlardı. ... Amma bu cümleden agreb Bağdad beğlerbeğisi iken kırk elli bin guruşluk gümüşden Kâh-1 Behişt nâm bir serîr ihdâs ider üzerinde yine sîm-i hâmdan eşcâr ve evrâk ve behâr ve turunç ve enâr makûlesi esmâr vaz‘ idüb bir vechle tertîb ve tezyîn ider ki, 'ukûl hayrân olur. Hatta kendisi Tokat kal'esinde mahsûr ve haremi ile hazînesi Bağdad'dan gelurken Celâlî Deli Hasan pençesine girer hazînesin siperler ile üleşürler ve Ravza'-i Beheşti Deli Hasan kurdurub eşkıyâsına seyrettirir." ${ }^{11}$

Peçevînnin sözünü ettiği bu tahttan daha sonra Nazmizâde Murteza, (öl. 1720 civ.) kuruluşundan 1717'ye dek Bağdat tarihini anlattığı eseri Gülşen-i Hulefầda da bahseder. Sultan III. Mehmed saltanatında Bağdat valisi olan Hasan Paşa'nın, Hasan Paşa Camisi adıyla maruf caminin revaklarını yaptırdığını; kendini beğenmiş ve çelebi karakteri ile tanındığını ve Bağdat valisi iken elli bin kuruşluk Kâh-ı Behişt (Cennet Sarayı) adlı üzeri ağaç, nar, narenciye ile bezeli görenleri hayran bırakan gümüş bir taht yaptırdığını söyleyen Nazmizâde Murteza, Peçevînnin naklettiklerini tekrar eder. ${ }^{12}$

Peki bir Osmanlı paşasının bu tür davranışları nasıl okunabilir ya da okunma1ı? Bir kişiyi Osmanlı elit ve/veya yönetici sınıfına dahil eden bileşenlerin maddi kültür boyutu kamusal alanda ne şekilde görünür oluyordu? Ne yazık ki Osmanlı kültür tarihi bağlamında maddi kültür ile kimlik oluşumu -yani kişiyi kendi toplumu ve sosyal sınıfı içinde diğerinden ayırt eden özellikler- ve bu kimliğin sunum biçimleri arasındaki ilinti, bazı değinmelerin dışında yeterince sorgulanmış bir konu değildir. Çok dilli, farklı etnik grupları barındıran Osmanlı toplumunda kimliğin çok yönlü bileşenlerden oluştuğu muhakkaktır; bilinen diller, mensup olunan aile ve memleket gibi. ${ }^{13}$ Maddi kültür boyutuyla düşündüğümüzde ise

11 Peçevî, Târîh-i Peçevî, s. 29-30.

12 Nazmi-zâde Murteza, Gülşen-i Hulefâ. Băgdat Tarihi 762-1717, haz. Mehmet Karataş (Ankara: Türk Tarih Kurumu, 2014), s. 193.

13 Osmanlı kimliğinin oluşumu bağlamında yapılan çalışmalarda daha çok etnik, dini ve sosyal sınıfın belirleyiciliği üzerinde durulmuştur; bu meselenin maddi kültür boyutu biraz geri planda kalmış görünmektedir. Bu konudaki bazı çalışmalar için bkz. Baki Tezcan, "Ethnicity, Race, Religion and Social Class: Ottoman Markers of Difference", The Ottoman World, ed. Chrisitine Woodhead (New York: Routledge, 2012), s. 159-170; Metin Kunt, "Ethnic- Regional (Cins) Solidarity in the Seventeenth-Century Ottoman Establishment," International Journal of Middle East Studies, 5 (1974), s. 233-239. 
kıyafet, kimliğin oluşumunda ve kamusal sunumundaki ana enstrümanlarından biriydi. Nitekim Osmanlı saray teşrifatında, özellikle de devlet törenlerinde giysilere verilen önem kıyafet ile temsilin devlet adamlarının kaygılarından biri olduğunu göstermektedir. ${ }^{14}$ Hedda Reindl-Kiel'in Silahdar Mustafa Paşa'nın 16351640 yılları arasındaki harcamalarını kapsayan iki Hazine defterinden yola çıkarak yaptığı çalışması, 17. yüzyılda bir Osmanlı devlet adamının lüks tüketimini ve bu tüketimin niteliğini göstermesi bakımından oldukça ilgi çekici sonuçlar içerir. ${ }^{15}$ Kuşkusuz buna benzer çalışmaların çoğalması, Osmanlı siyasasında elit sınıfın tüketim alışkanlıkları ve bu alışkanlıklar ile yaratmaya çalıştıkları kimlik ya da imge arasındaki bağlantıyı daha sarih kılacaktır. Bunun dışında Osmanlı kültüründe kıyafete verilen önem herkesin mensup olduğu sosyal ve dini gruplara uygun giyinmesi, kendinden daha 'üsttekilere' özenmemesi gerektiğinin sıkı kurallara bağlanmasıyla da karşımıza çıkar. Nitekim bu kuralların dışına çıkılma halleri dönem kaynaklarında eleştiri konusu olmuştur. Mesela, 1593-94'te, Gelibolulu Mustafa Alî Künhüll-Ahbâr'da sade ve gösterişsiz giysiler içinde olması gereken ulemayı ipekli ve kürklü giysiler giymekle, pahalı Arap atlarına binmekle suçlamaktadır. ${ }^{16}$

Yine benzer bir şekilde, 17. yüzyılda Koçi Bey, yöneticilerin ve halkın benzer giysiler giymesini sosyal sınıflar arasındaki ayrımın çözülmesinin örneği olarak verir. 16. yüzyılda, sadece yüksek mertebedeki devlet adamlarının mevkilerine uygun bir görkem içinde bulunmalarına rağmen 17. yüzyıla gelindiğinde iki hizmetkara bile sahip olmayan kişilerin görkem ve şatafat içinde etrafta dolaşmalarından şikayet eder:

Devlet-i âliyyede bu şöhret ve ziynet gibi zararı bulaşıcı bir bid'at daha yoktur. Rüstem Paşa’nın damadı Ahmed Paşa, ki Sigetvar seferinde dördüncü vezirdi, sonra vezir-i âzam oldu. İlk kez vezir olduğunda ihtişam aracı olarak ancak iki kürkü vardı; birini divan-1 hümayunda, birini de evinde giyerdi. Fakat dört, beş yüz satın alınmış kulu, ona göre de cebehanesi vardı. Diğer vezirler de bu şekildeydi. Kapıları [maiyetleri, adamları] mükemmel olup, her biri çiftliklerinde yüz

14 Rhoads Murphey, "Forms of Differentiation and Expression of Individuality in Ottoman Society", Turcica, 34 (2002), s. 135-141.

15 Hedda Reindl-Kiel, Leisure, Pleasure - and Duty. The daily life of Silahdar Mustafa, éminence grise in the final years of Murad IV (1635-1640), II, ed. Stephan Conermann ve Gül Şen (Berlin: EB-Verlag, 2016).

16 Jan Schmidt, Pure Water for Thirsty Muslims: A Study of Mustafā Ālì of Gallipoli’s Künhü l-Ahbār, (Leiden: The Oosters Instituut, 1991), s. 247-248. 
katar katır ve yüz katar deve beslerdi. Bir yere sefer olunsa, ferman geldiğinde bir at ve bir deve satın almayıp, üçüncü gün alelacele memur oldukları yere hareket ederlerdi. Kapı düzmeye ihtiyacı olmazdı. Şimdi ise asker taifesi, yüksek makam sahipleri ve başkaları [elde ettikleri] gelirlerini evlere, bağlara, köşklere ve samur kürklere ve ziynete verirler; [sefer] lazım gelse iki hizmetkârla bile çıkmaya kadir olamazlar. Şöhret afettir demişler, gerçekten de büyük afettir, işlerin doğrusu bu şekildedir. ${ }^{17}$

18. yüzyıla gelindiğinde, ait olunan sosyal grubun dışına çıkan giysiler giymenin, pahalı aksesuarlar ve de kıymetli eşyalar kullanmanın çok daha yaygın bir hale geldiği, 'alt sınıfların' statü olarak daha yüksek gruplara öykünerek onlarınkine benzer kıyafetler giymeye, eşyalar kullanmaya başladıkları görülür. Sultan III. Ahmed (sal. 1703-1736) ve III. Selim (sal. 1789-1808) dönemlerindeki fermanlarda, halkın gösterişli kıyafet giymeleri nev-zuhur bir adet olarak görülmüş ve yasaklanmıştır. Bu eleştirilerden özellikle kadınların kıyafetleri daha fazla pay almıstır. ${ }^{18}$

Örneklerden de anlaşılacağı üzere, dönem kaynaklarında sosyal sınıflar arasındaki ayrımın kaybolması, kişilerin sosyal ve ekonomik konumlarına uygun olmayan eşyaları kullanmaları 'düzeni' bozan uygulamalar olarak görülerek eleştirilmiştir. Ancak, 18. yüzyılın ya da popüler adıyla "Lale Devri” nin gösterişçiliği üzerine yapılan yeni çalışmalar, revizyonist Osmanlı tarihçiliğinin yeni yaklaşımlarından payını almış ve bu çalışmalarda gösterişçi tüketim kültürü ve bunun tezahür ettiği ritüeller bir safahat boşaltımından ziyade yeni bir iktidar sergileme biçimi olarak görülmüştür. Bu bağlamda, 18. yüzyılda, özellikle III. Ahmed devrinde, hanedanın vezirlerle evli kadın mensuplarının Haliç ve Boğaz kıyılarında inşa ettirdikleri sahil saraylarında sergiledikleri tüketim kültürüne dayalı görkemli hayat, hanedan ile elit arasındaki hem ortaklığın hem de rekabetin bir alanı olarak okunmuştur. 16. yüzyıl sonuyla birlikte siyasi sahnede güçlenen Osmanlı eliti, bu güçlerini hanedan kadınlarıyla kurdukları evliliklerle pekiştirmiş, görkemli yaşamlarılla da bir nevi hanedanı taklit ederken hanedan mensupları da aradaki sınırı korumaya yönelik çabalardan geri durmamışlardır. Bu taklit, dönemin kolektif iktidar anlayışı içinde meşruiyet aramanın bir yolu olarak görülmüştür. Yine, 18. yüzyılda, devlet ricalinin muhallefat kayıtlarına bakıldığında çok sayıda silah,

17 Koçi Bey, Koçi Bey Risaleleri, haz. Seda Çakmakoğlu (İstanbul: Kabalcı Yayınları, 2007), s. 82.

18 Betül İ. Argit, "An Evaluation of the Tulip Period and the Period of Selim III in the Light of Clothing Regulations”, Osmanlı Arasstrmalar/The Journal of Ottoman Studies, XXIV (2004), s. 12-17. 
at koşumları, kürk, kaftan, entari, top top değerli kumaşlar türünden hediyelik eşyalar, ayrıca ham elmas, zümrüt, yakut gibi değerli taşlar, kıymetli malzemeden yapılmış mutfak eşyaları, kişisel süs eşyaları dikkat çekmektedir. Bahsi geçen yeni çalışmalar, tüm bu hediyelik ya da kişisel kullanıma ayrılmış eşyaları, genel tarih yazımında söylenegeldiği gibi gösterişçi bir tüketim kültürünün tezahüründen ziyade önceki dönemlerde olduğu gibi yönetici elitin mal varlığını diğer iktidar ortaklarıyla paylaşmakta olduğunun göstergeleri olarak değerlendirmiştir. ${ }^{19}$

18. yüzyılla ilgili bu değerlendirmeler, Hasan Paşa’nın dış görünümü ve de davranışları ile kamusal alanda yarattığı bu şaşkınlık dolu etkiyi sadece kişisel bir tercih olarak görmemenin yeterli olmayacağını düşündürür. Daha açık bir ifadeyle söylersek, Hasan Paşa’nın fiziksel görünümü ve davranışları ile bir siyasetçi ve devlet adamı olarak kendini sunması ve var etmesi arasında bir ilişki olmalıdır. Yani Peçevînnin yukarıda nakledilen pasajında büyük bir şaşkınlıkla anlattığı Hasan Paşa'nın gösterişli giysileri, görkemli maiyeti, padişahlara yakışır tavırlar içinde Cumaya gidişi ve görenleri hem şakın hem hayran bırakan tahtı bir yandan siyasetçi olarak iddialarını gösterirken, diğer yandan da belli ki Osmanlı siyasasındaki 'sınırları' zorlamış ve de sınamışır.

Tüm bu imge yaratma sürecinde Peçevînin bahsetmediği bir başka araç daha vardı; resimli kitap hamiliği. Makalenin girişinde Sokullu Mehmed Paşa’nın resimli kitap hamiliğini siyasetin bir aparatı olarak ne kadar işlevsel bir şekilde kullandığına değinilmişti. Hasan Paşa da tıpkı babası gibi resimli kitapların hem içeriği ile hem de bir prestij göstergesi olarak Osmanlı siyaset sahnesindeki öneminin farkındaydı ve bu aracı siyasi ideal ve iddiasının bir göstergesi olarak kullanmaktan geri kalmadı. Makalenin bundan sonraki kısmında Hasan Paşa’nın kamusal imajının nedenini oluşturan siyasi hayalleri ve de bu bağlamda kendisi için yazdırdığı ve tasvirlerle süslettiği musavver elyazması üzerinde durulacaktır.

\section{Hasan Paşa'nın Padişahlık Hayalleri}

Sokulluzâde olmak, anlaşılan o ki Hasan Paşàya sadece ayrıcalıklı bir bürokrasi kariyeri sunmakla kalmamış, bir devlet adamı olarak siyasi alandaki iddiasını da belirlemişti. Hasan Paşa’nın yukarıda değinilen Bağdat valiliği sırasında sergilediği davranışları kendisini bir hanedan üyesi olarak gördüğ̈̈nü ve öyle davrandığını varsaymaya yetecek niteliktedir. Aslında, Hasan Paşa, Sokullu

19 Tülay Artan, "18. yüzyıl başlarında yönetici elitin saltanatın meşruiyet arayışlarına katılımı", Toplum ve Bilim, 83 (Kış, 1999), s. 299-302; 314-315. 
Mehmed Paşa ve İsmihan Sultan’ın evliğinden doğmamıştır; yani hanedanlıkla soy bakımından herhangi bir ilişkisi yoktur. Ancak Hasan Paşa hakkındaki sonraki yüzyılda karşımıza çıkan popüler bir anlatı farklı bir soy bağlantısı yaratarak kendini hanedanlığın bir üyesi olarak sunmaya çalıştığını yahut da böyle bir şayianın Osmanlıların gündeminde olduğunu düşündürür. Bu anlatı Mustafa bin Molla Rıdvan el-Bağdadi'nin Bağdat' in Osmanlılar tarafından fetihlerini anlattığ 1 Târîh-i Fetihnâme-i Bağdâd adlı eserinde karşımıza çıkar. Molla Rıdvan, kitabının hemen başında eserini yazma biçimi ve niyetini şöyle açıklar:

Kimini kütb-i tevârihden ve kimini görmüş ve işitmiş ihvândan görüb ve istimâ’ itmegin bu gune bir hevâdis zuhûr eyledi ki mecâlis ve mehâfilde okundukça hayr ile yâd oluna. ${ }^{20}$

Molla Rıdvan’ın aktarılan bu sözleri eserini çoğunlukla duyduğu/dinlediği sözel tarih anlatılarından meclislerde okunmak ve dinlenmek üzere yazdığını gösterir. Yani bu kitap, 'resmi tarihi' aktaran bir anlatıdan ziyade rivayetlerle örülü, zengin bir muhayyilenin neticesinde oluşan bir eserdir ve tam da bu bakımdan, yani daha az sesi duyulan bir 'tarihi' işitmemize olanak sağladığından, oldukça kıymetlidir. Bağdat valisi Hasan Paşa da Bağdat tarihinin içinde elbette ki yer alır ve Molla Rıdvan, Hasan Paşa’nın nesebiyle ilgili Osmanlı kroniklerinden oldukça farklı bir hikayeyi; belli ki 'popüler' tarih anlatılarında Paşa ile ilgili söylenenleri aktarır. Bu hikayede Hasan Paşa, Sokullu Mehmed Paşa’nın değil de Sinan Paşa adlı birinin oğludur. Dahası, annesi Sultan III. Murad'ın cariyelerindendir ve babası Sinan Paşa'ya hediye edildiğinde Sultan III. Murad'ın hareminden hamile olarak gelmiştir. Bu nedenle kendisinin Sultan Murad'ın oğlu olduğunu söyleyen Hasan Paşa şehzadelik davası etmiştir. ${ }^{21}$ Bu hikayenin tarihsel bir 'gerçekliğe' tekabül edip etmediği bir başka mesele olmakla birlikte, buradaki tartışma bakımından önemli olan bu tür bir söylentinin mevcudiyetidir. Belli ki yaşadığı dönemden itibaren sultanlara öykünen Hasan Paşa’nın bu davranışları zaman içinde kendisiyle ilgili bu tür hikayelerin oluşmasına vesile olmuştur. Üstelik Hasan Paşa, meşhur Sokullu ailesinin adı saltanatla anılan yegane üyesi de değildir.

Osmanlı tarihinde alternatif hanedan arayışları ne yazık ki çok irdelenmiş bir mesele değildir. Feridun Emecen bu konuda yazdığı ufuk açıcı makalesinde erken devirlerden itibaren özellikle kuruluş döneminde Evrenosoğulları gibi güçlü yerel

20 Târîh-i Fetihnâme-i Bağdâd, Oxford Bodleian Library, Or. 276, y. 64a-b.

21 Târîh-i Fetihnâme-i Bağdad, Oxford Bodleian Library, Or. 276, y. 64a-b. 
ailelerin ya da Şeyh Bedreddin (öl. 1420), Şah Kulu (öl. 1511) gibi dini liderlerin Osmanlı tahtında hak iddialarında bulunduğunu söyler. Kriz dönemlerinde hanedanlık alternatifi olarak Kırım hanlarının da öne çıktığını belirten Emecen, 17. yüzyılla birlikte bu tür alternatif arayışlarında niteliğin değiştiğine; ve hanedan üyeleriyle akrabalık bağı olan vezir ailelerinin hak iddialarıyla karşımıza çıktı̆̆ına dikkati çeker. II. Osman devrinde (1618-1622) hanedan üyelerini öldürmeyi planladığı iddia edilen Davud Paşa, sözgelimi, III. Mehmed'in kızıyla evliydi; yani Âl-i Osmân’ın damadıydı. 17. yüzyıl sonunda adı hanedanlık tartışmalarına karışan bir diğer güçlü vezir ailesi de soyları Sokullu Mehmed Paşa ve İsmihan Sultan'a dayanan İbrahimhanzâdelerdi. Ailenin adı özellikle 1703 Edirne Vakası olarak bilinen olayda, Osmanlı devletinin başına geçmesi önerilenler arasında anılmıştı. ${ }^{22}$ 17. yüzyıl ortalarında, muhtemelen IV. Murad devrinde (1623-1640) hazırlanmış bir Mecmua'da bu ailenin üyelerinden İbrahim Hanzâde'nin portresinin yer alması ise ailenin popülerliğini ve tüm bu söylentilerin Osmanlı görsel kültürü içindeki yansımasını göstermesi bakımından ilgi çekicidir (Resim 2). Belli ki Sokullu ailesinin üyelerinin gizli ya da örtük hanedanlık alternatifi olarak görülmesi, Hasan Paşa dışında da Osmanlıların gündemindeki konulardan biri olmuştur. $^{23}$

\section{Sultanlık İddiaları ve Kitaplar}

Sultanlık iddiaları Osmanlı kroniklerine çoğunlukla siyasi veçhesi ile yansımakla birlikte maddi kültür alanında bu iddianın beraberinde getirdiği davranış biçimlerinin olduğunu elbette ki öngörebiliriz. Nitekim bu tür davranışların ip uçları da tarihi kaynakların satır aralarında karşımıza çıkar. Mesela, Osmanlı tarihlerinde Celali ayaklanmalarını başlatan kişi olarak sunulan Sivas yöneticisi Karayazıcı Halim (öl. 1602) sultanlık iddiasında bulunmuş ve bu iddiasını dile getiren çeşitli uygulamalara girişmiştir. Karayazıcı Halim Osmanlı yöneticisi iken isyan ederek, kendine "Halîm Şâh-ı muzaffer badâ" yazılı bir mühür yaptırmış, emirlerini tıpkı bir Osmanlı sultanı gibi nişancısına yazdırmıştır. Dahası, eski bir Osmanlı yöneticisi olan Hüseyin Paşàyı kendine vezir yaparak tıpkı yeniçeriler

22 Feridun M. Emecen, "Osmanlı Hanedanına Alternatif Arayışlar Üzerine Bazı Örnekler ve Mülahazalar," İslâm Araştırmaları Dergisi, 6 (2001), s. 63-76.

23 Tülün Değirmenci, "An Illustrated Mecmua: The Commoners Voice and the Iconography of the Court in Seventeenth-Century Ottoman Painting," Ars Orientalis, 41 (December, 2011), s. 207208. 


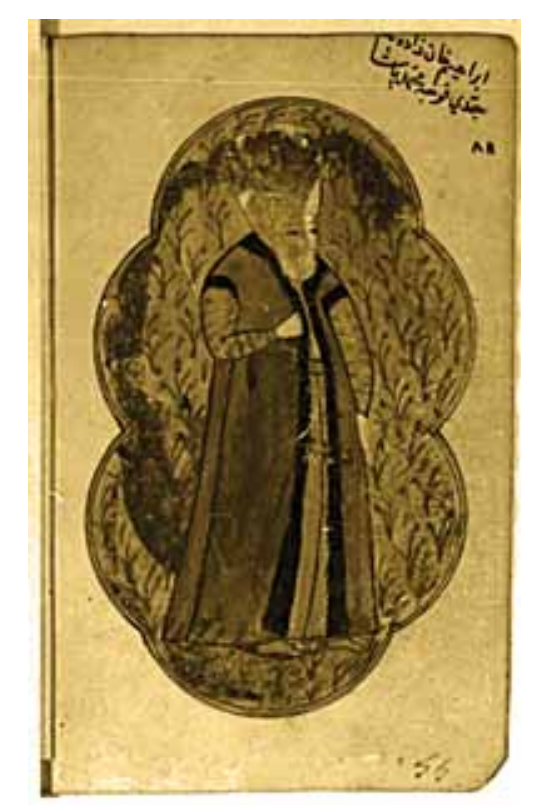

Resim 2 Mecmua, Bibliothèque nationale de France, Paris, Turc 140 , v. $29^{\text {b }}$.

gibi askeri birlikler oluşturmuş ve de soyunun 'eski şahlara' bağlandığını iddia etmiştir. ${ }^{24}$ Karayazıcı Halim'in bu davranışları yukarıda bahsedilen Hasan Paşa’nın kendine hazinedar olarak atadığı gençle olan ilişkisini akla getirmektedir. Paşa’nın kendi giysilerinin bir benzerini ona giydirmesi, gittiği her yere onu da beraberinde götürmesi, hatta resmi kabullerinde gelen kişilerin önce etrafındakilerle görüşmesi gibi uygulamaları Peçevînnin de ifadesi ile "ashâb-1 devletten birinden görmek ve işitmek vaki“” olmamıştı; yani daha önce benzeri hiç görülmeyen garip işlerdi.

Yine 17. yüzyılda, sekban toplayarak Manisa’yı işgal eden Balıkesir yöneticisi İlyas Paşa da geceleri Şehnâme ve Tîmûrnâme okutarak padişahlık hayalleri kuruyordu. Tarihçi Na îmâ Mustafa Efendi’nin söylediklerine göre, İlyas Paşa Manisa’yı işgal edip üç gün burada kaldıktan sonra tekrar Balıkesir'e dönmüş ve asker sayısını daha da artırmıştır. Bu vaziyetteyken geceleri Şehnâme tercümesi ve Timur'a ait hikayeleri okutup dinleyerek hayallere dalmıştır:

24 Baki Tezcan, "Searching for Osman: A Reassessment of the Deposition of the Ottoman Sultan Osman II (1618-1622)” (doktora tezi), Princeton University, 2001, s. 124; Selânikî Mustafa Efendi, Tarih-i Selânikî (971-1003/1563-1595), I-II, haz. Mehmet İpşirli (Ankara: Türk Tarih Kurumu Yayınları, 1999), s. 834. 
Bu vak'adan sonra yine Balıkesiri'ye gelip karar eyledi. Tekebbür ü cevri evvelkinden ziyâde oldu ve askerin muzấaf edip cihangirlikten dem urmağa başladı ve gecelerde Şehnâme tercümesi okudup istimâ‘ ederdi ve gâhîce Timurlenk hikâyeleri okudurdu. Dimâğı hayâl-i Muhâl ile dolup her çend Asitâne'den müdâra olunurdu. ${ }^{25}$

Yerel güçlerin yönetimle ilgili bu iddiları okuyacakları kitapların türlerini belirlemerinde de etkili olmuştur. Nitekim Osmanlı yönetim felsefesi üzerine yazılmış dönem kaynaklarında da yöneticilerin okuması gereken kitaplar özenle belirlenmiştir. 16. yüzyıl Osmanlı yazarlarından Kınalızâde Ali Efendi'nin (1516-71) Osmanlı devlet ve cemiyet anlayışını ve bu kapsamda Osmanlı devletinin yönetim felsefesini incelemek üzere yazdığı Ahlâk-ı Alầ adlı eserde ideal hükümdarın nitelikleri anlatılır. Sayılan özelliklerden biri ideal bir hükümdarın "reyde ve fikirde, görüş ve düşüncede isâbet" sahibi olması gerektiğidir. Bu haslet iki şekilde elde edilir: Birincisi, yaradılıştan itibaren zeki ve akıllı olmak, ikicisi de yaşananlardan ders almak, geçmiş tecrübeleri değerlendirmektir. Bir sultan genç olduğundan dolayı yeterli tecrübeye sahip olmayabilir. Bu nedenle de her genç hükümdar "tevârîh" ve "ahbâr" kitapları okumalıdır. Bu tür kitaplar geçmiş hükümdarların durumlarının aynası gibidirler. Geçmişte olan olayları bildirirler, aynı zamanda da ibret ve tecrübe örnekleriyle doludurlar. Bu tecrübeler bin bir türlü zorluk sonucu elde edildiğinden akıllı bir hükümdar bunları okuyup değerlendirerek ders çıkarır. Bu tür kitapların en iyisi Şehnâme-i Firdevsî̀dir. Bu kitabı okumak sultana hem "şecâat ve şehâmet" yani iyilik ve kahramanlık kazandırır, hem de pek çok faydalı tecrübeler ihtiva ettiğinden yol gösterir. ${ }^{26}$ Benzer bir şekilde, 17. yüzyıl sonunda yazıldığı düşünülen bir şikâyet mektubunda, mektubun anonim yazarı Osmanlı sultanlarının ataları gibi başarılı olabilmeleri için Tevârîh-i Âl-i Osmân ya da Şehnâmèden hikâyeler okuyarak geçmişin başarılarını öğrenmelerini ve buna uygun davranmalarını öğ̈̈tler. ${ }^{27}$

25 Na îmâ Mustafa Efendi, Târih-i Na îmầ (Ravzatüll-Hüseyn Fî Hulâsati Abbâri'l-Hâfikayn) I-IV, haz. Mehmet İpşirli (Ankara: Türk Tarih Kurumu Yayınları, 2007), s. 734-735.

26 Kınalızâde Ali Çelebi, Ablâk-ı Alầ, haz. Mustafa Koç (İstanbul: Klasik Yayınları, 2007), s. 468; Fahri Unan, İdeal Cemiyet, İdeal Devlet, İdeal Hükümdar (Ankara: Lotus Yayınları, 2004), s. 191-192.

27 Bugün Leiden Üniversitesi, Werner Koleksiyonu'nda bulunan mektup (Cod. Or. 728) Süheyl Ünver tarafından yayınlandı. Bkz. Süheyl Ünver, "XVII inci Yüzyıl Sonunda Padişaha bir Lâhiya”, Belleten, XXXIII (1969), s. 21-24; Ayrıca koleksiyonun katoloğu için bkz. Jan Schmidt, Catalogue of Turkish Manuscripts in the Library of Leiden University and other Collections in the Netherlands, cilt I (Leiden: Legatum Warneriaum, 2000), s. 225-227. 
Yüzyıllar içinde bürokrasinin gereksinimleri değişmiş, yeni şartlar yeni tip devlet adamlarının yetişmesini, yani yeni bir Osmanlı kimliğinin oluşmasını gerekli kılmıştır. Mesela 18. yüzyılla birlikte Avrupa ile olan bürokratik ilişkilerin artmasıyla birlikte buna uygun uluslararası politikada mahir ve dil yeteneğine sahip devlet adamlarına ihtiyaç artmıştır. Buna rağmen hükümdarlara öğütler içeren ya da model olacak davranışların yer aldığı kitaplar her zaman okunması salık verilen eserler olmuştur. Bürokratların $E d e b$ eğitimi için hükümdarlara öğ̈̈tler içeren Humâyûnnâme ya da yukarıda değinilen Ablâk-ı Alầ̂ hala en önde gelen eserler olmaya devam etmiştir. 18. yüzyllın önemli katiplerinden ve de devlet adamlarından Râtib Efendi, Orientalische Academienin kütüphanesini ziyareti sırasında gördügü siyaset fenni hakkındaki bir kitapla ilgili mihmandarından bilgi isteğinde İslam dünyasında bu tür kitapların olmadığı cevabını alması üzerine hemen yukarıda söylenen kitapları buraya yollatmıştır. ${ }^{28}$

Görüldügü gibi kitap, türü ve içeriği bir yana tek başına bile yönetici ve devlet adamı olmanın, yönetici sınıfına dahil olmanın simgelerinden biridir. İçeriği ile hükümdarlara ya da etrafındaki devlet adamlarına hem yol gösteren hem de hamisinin metin ya da resim içeriğine dahil edilmesi ile politik söyleminin bir parçası olan bu elyazmaları aynı zamanda birer lüks tüketim objesi olarak da prestijlerinin göstergesi olmuşlardır. Nitekim, 18. yüzyılda Osmanlı devlet adamlarının muhallefat kayıtlarından çıkan kıymetli kitapları inceleyen Tülay Artan, bu eserlerin içeriklerinden ziyade birer lüks tüketim objesi olarak onların zenginliklerinin timsali olduğunu düşünür. ${ }^{29} \mathrm{Bu}$ kadar kıymetli olmalarından olsa gerek ki, özellikle elçi kabulü gibi diplomatik ilişkileri belgeleyen tasvirlerde elçilerin sunduğu hediyelerin başında kitaplar gelmiştir. Ve Hasan Paşa da siyasi alanda iddiaları olan bir Osmanlı eliti olarak yöneticilik iddialarının gereğini yerine getirmiş; yukarıda da belirtildiği gibi Bağdat valiliği sırasında kendisi için musavver bir tarih kitabı yaptırmıştır.

\section{Hasan Paşa ve Câmi 'ü's-Siyer}

Hasan Paşa’nın bir nevi sürgün olarak gittiği Bağdat şehri ona kariyerinin en renkli ve de üretken günlerini yaşaması için olanak sağlamıştır. Bağdat sadece Osmanlı İmparatorluğu’nun önemli bir eyalet merkezi değil aynı zamanda resimli

28 Fatih Yeşil, "How to be(come) an Ottoman at the end of the Eighteenth Century", Osmanlı Arasttrmalarl/ The Journal of Ottoman Studies, XLIV (2014), s. 124-131.

29 Tülay Artan, "18. yüzyıl başlarında yönetici elitin”, s. 310. 
kitapları ile nam salan eyalet merkezlerinden en ünlüsüdür. ${ }^{30}$ III. Murad'ın saltanatının son yılları ile III. Mehmed devrinde Bağdat'ta hazırlanan resimli elyazmaları Osmanlı resimli kitapları içinde özel bir grubu oluşturur. "Bağdat ekolü” olarak tanımlanan bu gruptaki eserler, hem konuları, hem de tasvirlerinin üslup ve ikonografisi ile başkent örneklerinden belirgin bir biçimde ayrılırlar. Resimlenmek üzere seçilen metinlere bakıldığında, daha çok Şii çevrelerce rağbetle okunan, İslam dünyasının kutsal şehitlerini konu alan kitapların belirgin bir şekilde tercih edildiği görülür. Bu kitaplar arasında, Bağdatlı şair Fuzûlînnin (öl. 1556) Kerbelâ şehitlerini anlatan Hadîkatü's-süedâ’sı, ünlü mutasavvıf Lâmi Çelebi'nin (öl. 1532?) Hz. Muhammed'in yakınlarının şehit olmasını konu alan Maktel-i $\hat{A l-i}$ Resûlü gibi eserler yer alır. Bunların yanı sıra, Şehnâme gibi edebi eserler ya da tarih metinleri de resimlenerek geniş bir konu yelpazesi oluşturulmuştur. ${ }^{31}$ Bağdat'ta hazırlanan resimli eserlerin tarikat mensuplarınca okunan kitaplar olması, ayrıca, resimlerde sıklıkla dervişlerin yahut tarikat yaşamına ait ayrıntılı betimlemelerin görülmesi, bu eserlerin şehirde bulunan Mevlevi dergâhlarında hazırlandığının düşünülmesine yol açmıştır. ${ }^{32}$

Bağdat’a atfedilen resimli elyazmaları sadece içerikleriyle değil, üslup özellikleriyle de İstanbul'da hazırlanan resimli kitaplardan farklıdır. Daha çok tarih metinlerinin resimlenmek üzere tercih edildiği saray nakkaşhanesinin ağırbaşlı ve ciddi üslubu ile karşılaştırıldığında, Bağdat resimlerinde daha dinamik ve neşeli bir anlatım görülür. Şehir hayatının gündelik ayrıntıları ile zenginleştirilmiş kompozisyonlar, oranları ile oynanmış, hatta karikatürize edilmiş ve kimi zaman

30 Abbasi Halifesi Cafer el-Mansur tarafından 766 yılında “yuvarlak şehir” olarak kurulan Bağdat Horasan yolu üzerinde, Dicle ve Fırat Nehri arasındaki verimli topraklar üzerinde yer almaktadır. Kuruluşundan itibaren önemli bir kültür merkezi olan şehrin nüfusu kısa süre içinde artmıştır. İslam dünyasındaki çeviri hareketine de ev sahipliği yapan, ilk büyük kütüphane olan BeytülHikme'nin kurulduğu yer olan Bağdat tarihi boyunca önemli bir kitap üretim ve tüketim merkezi olmuştur. A. Duri, "Baghdād”, The Encyclopedia of Islam (New Edition), 1986, I, 894-899; şehir hakkında detaylı bilgi için bkz. Guy le Strange, Baghdad during the Abbasid Caliphate from Contemporary Arabic and Persian Sources, (Westport: Greenwood Press, 1977).

31 Rachel Milstein, Miniature Painting in Ottoman Baghdad, (Costa Mesa: Mazda Publishers, 1990), s. 7-36; Serpil Bağcı, Osmanlı Resim Sanatı, (İstanbul: Kültür Bakanlığı Yayınları, 2006), s. 256257. Bağdat resim okulu hakkında son zamanlarda hazırlanmış bir çalışma için ayrıca bkz. Melis Taner, "Caught in a Whirlwind: Painting in Baghdad in the Late Sixteenth-Early Seventeenth Centuries" (doktora tezi), Harvard University, 2016.

32 Filiz Çağman, "XVI. Yüzyıl Sonlarında Mevlevi Dergahlarında Gelişen Bir Minyatür Okulu”, I. Milletlerarası Türkoloji Kongresi, 3. Türk Sanatı Tarihi (İstanbul: Kültür Bakanlığı, 1979), s. 651677. 
sahne marjından taşan figürlerle yaratılan bu resimler sadece farklı bir resim dilinin temsilcileri olmakla kalmaz, 16. yüzyıl sonu Bağdat'ına dair zengin bilgiler sunan birer görsel "belgeye" dönüşürler.

Bağdat atölyelerinin 16. yüzyıl sonu, 17. yüzyıl başında canlanması ile Hasan Paşảnın şehre vali olarak gelmesi arasında bir bağ olduğu kuşkusuzdur. Ancak bu yoğun üretim arasında Hasan Paşa için yapıldığını kesin olarak bildiğimiz iki resimli elyazması vardır. Bunlardan ilki Fuzûlînnin şarap ve esrar üzerine yazdığı Farsça bir mesnevisi olan Beng ü Bâde adlı eseridir. Ketebe kaydına göre, bu eser Hasan Paşa için 1599-1600 arasında istinsah edilmiştir. Mevleviliğe karşı ilgisi, Konya’daki Mevlana dergâhı için yaptırdığı gümüş kapı ile aşikâr olan Hasan Paşa’nın ${ }^{33}$ Beng ü Bâdéyi resimletmesi tasavvufi eğilimlerinin bir sonucu olmalıdır. Hasan Paşa için yapılma olasılığı olan bir diğer eser de bir Silsilenâme nüshasıdır. Adem Peygamber'den başlayarak, İslam dininin kabul ettiği nebi ve velilerin, İslam öncesi İran şahlarının ve Müslüman hanedanlarının yöneticilerinin ve de son olarak Osmanlı sultanlarının portrelerinin kronolojik bir eşgüdüm içinde birbirine bağlanan madalyon portreler şeklinde düzenlendiği bu elyazmaları, 16 . yüzyıl sonu 17. yüzyıl başı Bağdat atölyesinin en önemli eser grubu arasındadır. $\mathrm{Bu}$ yazmaların Bağdat'ta yöneticilik yapan Osmanlı devlet adamları tarafından başkente hediye edilmek üzere yapıldığı düşünülür. ${ }^{34}$ Şehrin en meşhur yöneticilerinden olan Hasan Paşa’nın da benzer bir politik amaçla Silsilenâme yaptırmış olabileceği varsayılabilir. Bu bağlamda, tarih olarak daha geç bir dönem olmakla birlikte, 18. yüzyılda, Damat İbrahim Paşa’nın muhallefatında kayıtlı 160 cilt kitap arasında 'musevvirât-ı selâtin' yani sultan resimlerinin bulunması ilgi çekici bir benzerliktir. Silsilenâme biçiminde olan bu padişah portrelerini Damat İbrahim Paşa sultanlara hediye etmek üzere mi yaptırdı yahut da sultan tarafindan kendisine mi hediye edildi bilinmemekle birlikte, bu tasvirlerin Paşa’nın Osmanlı soyuyla olan akrabalığa verdiği önemle bir alakası olduğu düşünülür. Nitekim benzer bir şekilde Merzifonlu Kara Mustafa Paşảnın Viyana seferi öncesi IV. Mehmed'e tasvirli bir Silsilenâme hediye ettiği, son satırında 'fatih' olarak hitap edilen Sultan'a yeni fetihler temenni edildiği bilinmektedir. Yine hanedanla akrabalığı olan aynı dönemin ricalinden Kaymak Mustafa Paşa'nın muhallefatında

33 Serpil Bağcı, “Seyyid Battal Gazi Türbesi’nin Gümüş Kapısı Üzerine Bazı Gözlemler,” Dokuzuncu Milletlerarası Türk Sanatları Kongresi, Bidiriler, I, (Ankara: Kültür Bakanlığı Yayınları, 1995), s. 226.

34 Serpil Bağcı, “Adem’den III. Mehmed'e: Silsilenâme”, Padişahın Portresi: Tesavir-i Âl-i Osman, (İstanbul: Türkiye İş Bankası Kültür Yayınları, 2000), s. 197-201. 
Şemailnâme'ye (padişah portreleri); Kethüda Mehmed Efendi'nin ise resimli iki cilt Şehnâme, Timurnâme ve İskendernâmèye sahip olmaları hanedanlığa olan öykünmelerine işaret olarak yorumlanır. ${ }^{35}$ Osmanlı soyu ile akrabalık meselesinde bu tür kitapların oynadığı rol, daha önce de tartışıldığı gibi padişahlık hayallerinden çok uzak olmayan Hasan Paşảnın da bir Silsilenâme yaptırmış olabileceği ihtimalini kuvvetlendirmektedir.

Bahsi geçen Silsilenâmènin, Hasan Paşa için yapıldığı bir ihtimal olmakla birlikte Silsilenâméde görsel olarak sunulan İslam tarihinin adeta metinle birleştirilmiş ve de uzatılmış versiyonu olan Câmi üss-Siyer, Hasan Paşa için resimlendiğini kesin olarak bildiğimiz ikinci eserdir. Evrenin yaradılışından 14. yüzyıla kadarki İslam tarihinin belirli süreçlerini içeren bu kitap, doğrudan Hasan Paşånın isteği doğrultusunda yeni yazılmış bir metin olması bakımından oldukça kıymetlidir.

Topkapı Sarayı Koleksiyonunda bulunan Câmi üs'Siyer'in bilinen yegane nüshası iki kitaptan oluşur. İlk kitabın (H. 1369) mukaddimesinde "bir mukâddime, altı defter ve bir hâtîme üzere tertîb olunub" denilerek eserin altı defter, bir mukaddime ve hatime olarak planlandığı belirtilir. ${ }^{36}$ Ardından her bir defterin içeriğinin başlıklar halinde yazıldığ göre, ilk defterde yaradılış, gökyüzü ve yıldızlar; ikinci defterde İslamiyet öncesi peygamberler ve hanedanlar; üçüncüsünde Hz. Muhammed'in zamanı ve İmam Hasan ve Hüseyin'in şehadeti; dördüncüsünde Emevi tarihi; beşinci defterde Emeviler'den Abbasiler'e geçiş dönemi; altıncı defterde ise Abbasiler ve çağdaşı olan hanedanlıkların tarihi anlatılmaktadır. Hâtime, bölümü ise Hasan Paşa’nın fetih ve başarılarına ayrılmıştır. ${ }^{37}$ İlk kitap, indekste de belirtildiği gibi evrenin yaradılışı (gezegenler, yıldızlar vs) başlar ve erken dönem Abbasi tarihine kadar devam eden süreci içerir; yani altıncı deftere kadarki bölümler bu nüshada yer alır. Elyazmasının başında ve sonunda yer alan mülkiyet kaydına göre kitap, 174243 yılında Dimetoka’nın Bazarbegli bölgesinden Kuçek Ali Ağa oğlu Kuçek elHac Muhammed'in elinde bulunmaktadır. Bu kayıt kitabın Saray koleksiyonuna

35 Tülay Artan, "18. yüzyıl başlarında yönetici elitin”, s. 309-310.

36 Eser toplam 577 varaktır. Nestalik hatla yazılmıştır. Hem metin hem de tasvirler yarım kalmıştır. 42 tasvirle resimlenmesi planlanmış ancak bu tasvirlerden ancak yedisi tamamlanmış, 35 tasvir için ayrılan yer ise boş kalmıştır. Kitabın sadece tasvirleri yarım kalmamıştır, kimi sayfalarda cetveller de çekilememiştir. Bazı varaklarda başlıklar için ayrılmış kartuşların içi boş kalmış; son varaklarda ise el yazısı değişmiştir. Metin yarım kalarak sonlanmıştır.

37 Câmi ǘs-Siyer, TSMK. H. 1369, v.16a-b. 
gelmeden önce bir süre dolaştığını gösterir. Kim bilir belki de Hasan Paşa’nın Tokat Kalesi'nde Deli Hasan tarafından yağmalanan hazinesi içinde bu kitap da yer alıyordu ve bu yolla dışarı çıkmıştı.

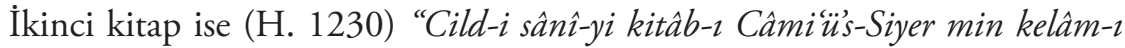
Muhammed el-Tahir" ibaresi ile başlar. ${ }^{38}$ Metnin hemen başında Allah'a ve Peygamber'e övgünün ardından Sultan III. Mehmed'i metheden kısa bir bölüm yer alır. Ardından yazar birinci cildin itmamının ardından ikinci cilde başladığını ve onun "müzeyyen" ve "müzeyyel” bir kitap olarak yazdığını belirtir. Metin Abbasiler'den başlar ve 14. yüzyıla, İlhanlı dönemine kadar devam eder. Yani, bu cilt, H. 1369'da yer alan indekste belirtilen altıncı defteri içerir. Bu indekse göre, en son olarak Hasan Paşa'nın başarılarını anlatacak olan Hatime bölümün de burada yer alması gerekmekle birlikte eser tamamlanamadığından dolayı bu bölüm yer almaz.

Her iki elyazmasının da fiziksel özellikleri -metin ve resimlerinin yarım kalması; farklı el yazılarının bir arada olması gibi- hem bir nedenle tamamlanamadıklarını hem de bu iki kitabın birbirinin devamı olan iki cilt olamayacağını düşündürür. Ancak, ilk kitabın mukaddimesinde yer alan ve yukarıda bahsi geçen indeksteki defter kelimesi çağdaş araştırmacılar tarafından cilt olarak anlaşılmış ve eserin altı cilt olarak planladığı ancak ilk iki cildinin tamamlanabildiği şeklinde yorumlanmıştır. ${ }^{39}$ Oysa eserin içeriğine bakıldığında ilk cilt olarak kabul edilen birinci kitabın ilk beş defteri tamamıyla altıncı defterin de baş kısmını halihazırda içerdiği görülmektedir. Dolayısıyla ikinci kitap, belki de bir ek niteliğinde düşünülmüştür. Yahut da, farklı yazı türlerinin kullanıldığı bu iki kitap iki ayrı takımın parçalarıdır.

Her iki kitapta da ketebe kaydı yoktur. İlk kitapta yer alan mukaddime bölümünde verilen bilgilere göre, eser Bağdat valiliği sırasında Hasan Paşa için hazırlanmıştır. Bu bilgiden eseri 1598 ile 1602 tarihleri arasına rahatıkla yerleştirebiliriz. Giriş bölümünde isminin Muhammed Tâhir el-Sıddîkî el-Necibî el-Sühreverdî olduğunu belirten müellif, Hasan Paşảnın Bağdat'taki bütün

38226 varaktır ve tezhipli bir serlevha ile başlar. Metin başlamadan hemen önceki boş sayfada eserde dokuz tasvirin olduğunu belirten bir not alır ve bu notta da belirtildiği gibi elyazmasında dokuz tamamlanmış tasvir, bir de resimlenmek üzere ayrılmış ancak tamamlanamamış boş sayfa yer alır. Nesih hatla yazılmış bu cilt ilkine oranla hem metin hem de resimler bakımından daha sağlam durumdadır.

39 Milstein, Miniature Painting, s. 110-111. 
eşkıyaları kontrol altına aldıktan sonra hizmetinde bulunduğu esnada kendisine erken İslam devrini anlatan bir tarih kitabının olup olmadığını sorduğunu; kendisinin de bu soruya Arap ve Fars dilinde olduğunu söyleyerek cevap verdiğini belirtir. Bunun üzerine Hasan Paşa’nın, her iki dili de iyi bilmesine rağmen, devlet adamlarının sohbetlerinde bu tarihi tartışmaları için Türkçe olarak yazılmasını münasip bulduğunu aktarı:

Du'â-yı devâm-1 devletlerine kıyâm gösterüb mülâzemet esnasında Hulefâ-yı Râşidîn ve Selâtîn-i ma'delet âyînlerinin ahvâlinden istifsâr ve ba ğzı vekâi'lerinden istihbâr sordılar. Bu fakîr, leb-i edeble hıdmetlerine 'arz eyledi ki lisân-1 'Arabî ve zebân-1 Fârsîyle tahrîr olunmuşdır. Saâdetle sordılar ki Türkî dilince olsa münâsibdir. Egerçe vücûd-1 şerîfleri hilye-i ma ârifle ârâste ve zât-1 latîfleri 'ilm u kemâl ile pirâste ki lisân-1 'Arabîde tarîk-i hasâne sâlik ve Fârsîde makâmât-1 Selmâne mâlikdir. Lakin ba ğzı âshâb-1 devlet ki şeref-i sohbetleriyle müşerref olub istimâğından mahzûz olurlar. ${ }^{40}$

Bu ifadelerin ardından, böylesine bir işle, yani Hasan Paşa için Türkçe olarak yeni bir tarih kitabının yazılmasıyla görevlendirilen yazar ismini Muhammed Tâhir el-Sıddîkî el-Necibî el-Sühreverdî olarak açıç̧a yazar. Ne yazık ki Muhammed Tâhir'in ismine Osmanlı biyografi kaynaklarında rastlanmaz. Yazarın kimliği hakkında spekülasyon yapabilmeyi mümkün kılan yegane ip ucu "elSıddîkî el-Necibî el-Sühreverdî” nisbesidir. Bu unvan yazarın Bağdat'ta yetişen ve Dicle kenarında kendisi için bir tekke ve medrese inşa edilen ünlü sufî Ebü’nNecîb Sühreverdî (öl. 1168) ile olan bağlantısını göstermektedir. Ebü’n-Necîb Sühreverdînnin yanında yetişen yeğeni Ebû Hafs Ömer es-Sühreverdî daha sonra Sühreverdiye tarikatını kurmuştur. ${ }^{41}$

Tekrar yukarda aktarılan ifadelere dönersek, müellifin bu kitabın yazılma amacıyla ilgili olan sözleri oldukça ilginçtir. Zira burada Câmi ús-Siyerìn, devlet adamları tarafından sohbetlerde okunmak/dinlenmek üzere, yani edebi bir mecliste sözel olarak kullanılmak amacıyla yazdırıldığı belirtilir ki bu niyet aşağıda tartışılacağı üzere Hasan Paşa’nın Câmi ứs-Siyerì politik söylemini bir propaganda aracı olarak kullanma biçimine de oldukça uygun düşmektedir. $\mathrm{Bu}$ bağlamda Câmiứs-Siyerìn hamisi Hasan Paşa tarafından politik bir araç olarak

40 Câmi üs'Siyer, TSMK. H. 1369, v.15b.

41 R. Öngören, “Sühreverdî, Ebü’n-Necîb”, Türkiye Diyanet Vakfı İslâm Ansiklopedisi, (38, 2010) s. $35-36$. 
kullanılmasını anlamak üzere eserin mukaddime bölümüne ve bu bölümde yer alan tasvirlerin ikonografisine detaylı bir şekilde bakmak aydınlatıcı olacaktır. Nitekim, özellikle tarih metinlerinde önsöz bölümlerinin kitabın iletmek istediği ideolojik mesajları, eserin yüklendiği anlamları, hamileri tarafından kullanılma biçimini; kısacası kitabın ötesindeki manaları anlamak üzere oldukça işlevsel olduğu farklı alanlardaki çalışmalarda dile getirilmiş bir meseledir. ${ }^{42} \mathrm{Bu}$ sebeple de, makalenin bundan sonraki kısmı Câmi 'u's-Siyer'in mukaddime bölümünün metin ve resim analizine ayrılmıştır.

Câmi ús-Siyer'in ilk cildi, Allah'a ve Hz. Muhammed'e övgüden hemen sonra kısa bir Osmanlı tarihi bölümü ile başlar. Burada Kanuni Sultan Süleyman devrinden Sultan III. Mehmed dönemine kadar meydana gelen olaylar ayrı başlıklar altında kısaca anlatılır. Osmanlı sultanlarına ayrılmış bu ayrı bölümler belirli bir anlatım şemasını takip etmez, aksine her bölümün vurgusu farklıdır. Mesela, Kanuni devrine ayrılan bölümde Zigetvar Seferi (1566) anlatıllır. ${ }^{43}$ Dahası bu bölümde bütün seferin detaylı anlatımından ziyade daha çok Kanuni'nin sefer esnasında vefatı ve bu haberi saklamak üzere Sokullu Mehmed Paşånın aldığı önlemler üzerinde durulur.

Daha önce de zikredildiği gibi, ilk cildin (H. 1369) tasvirlerinin büyük bir kısmı tamamlanmamıştır. ${ }^{44}$ Var olan tasvirlerden ikisi mukaddime bölümünde yer alır. Elyazmasının ilk tasviri yukarıda belirtilen satırlara eşlik eder ve burada Kanuni Sultan Süleyman’ın Zigetvar kuşatması esnasında çadırında Sokullu

42 Bu bağlamda, S. A. Quinn’in Safevi Şahı Abbas döneminin (1571-1629) tarih yazımını irdelediği kitabında bu dönemde yazılmış tarih kitaplarının önsözleri üzerine yaptığı analiz zihin açıcıdır. Quinn’e göre, Şah Abbas döneminde yazılan tarih kitaplarının önsözlerinde üç farklı bölümde değiştirmeler yapılır: Allah'ın ve peygamberlerinin methedildiği dini övgü bölümü, yazar hakkında bilgi verilen kısım ve eser hakkında bilgi verilen bölüm. Bu üç bölümde meydana gelen sapmaları, yazarın kişisel geçmişi ve mensubu olduğu güç grubu, eserin yazıldığı dönemin siyasi sorunları-Kızılbaş meselesi- ve Şah Abbas'ın politik ve dünya görüşü içinde analiz eden Quinn, her bir değişikliğin Şah Abbas'ın meşruiyetini sağlamaya yönelik olduğu sonucuna varır. Bkz. Sholeh A Quinn, Historical Writing during the Reign of Shah Abbas: Ideology, Imitation, and Legitimacy in Safavid Chronicles, (Salt Lake City: The University of Utah Press, 2000), s. 33-61.

43 Câmi ḯs-Siyer, TSMK. H. 1369, v.4a-6b.

44 Geriye kalan resimlerde çoğunlukla erken İslam ve İran tarihinden konular canlandırılmıştır. Afrasyab'ın savaşı, Çin Hakanı'nın Büyük İskender'in elçisini kabulü, Behmen'in fil öldürmesi, 636 yılında Müslüman Araplar ve Sasaniler arasında gerçekleşen Kadisiye savaşı betimlenen konular arasındadır. 


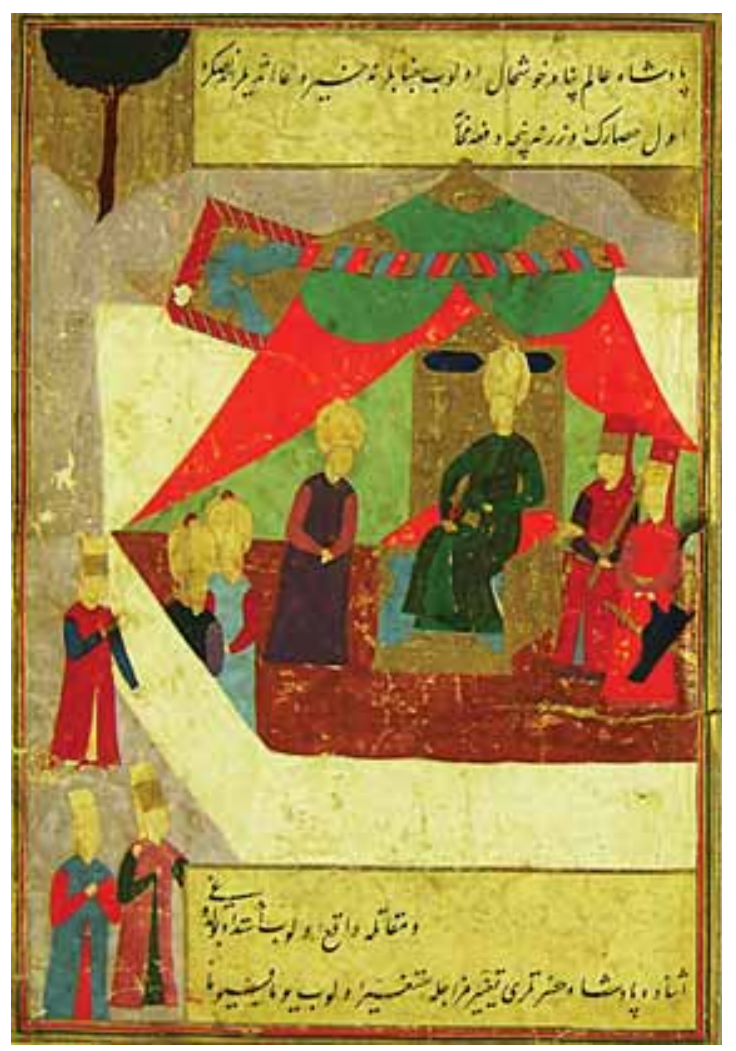

Resim 3 Câmi iưs'Siyer, TSMK. H. 1369, v. 6a.

Mehmed Paşa'yı kabulü betimlenir (Resim 3). Resimde Kanuni Sultan Süleyman padişah otağı içine kurulmuş çadırında, tahtı üzerinde oturur. Hemen arkasında sultani ikonografyanın ayrılmaz parçası olan iki has oda ağası yer alır. Sultan'ın hemen huzurunda ellerini önde saygı ile birleştirmiş Osmanlı paşaları vardır. Bunlardan daha önde duran Sokullu Mehmed Paşa olmalıdır. Tasvirdeki tüm figürlerin yüzü tamamlanamamış, boş bırakılmıştır. Osmanlı resimli tarih kitaplarında sıklıkla rastladığımız kabul sahnesi ikonografisini tekrar eden bu tasvir, Bağdat üslubundan çok saray nakkaşhanesinin yerleşik kalıplarını tekrar eder. Yani bu tasvir üslubundan ziyade konusu ile ilgi çekicidir.

III. Murad'ın saltanatının anlatıldığı bölümde de bu devirde meydana gelen bütün olayları sıralamak yerine yazar ağırlıklı olarak Sokullu Mehmed Paşa’nın öldürülmesi üzerinde durur. ${ }^{45}$ III. Mehmed devrine gelindiğinde ise anlatımın 45 Câmi iủs-Siyer, TSMK. H. 1369, v. 8b-10b. 


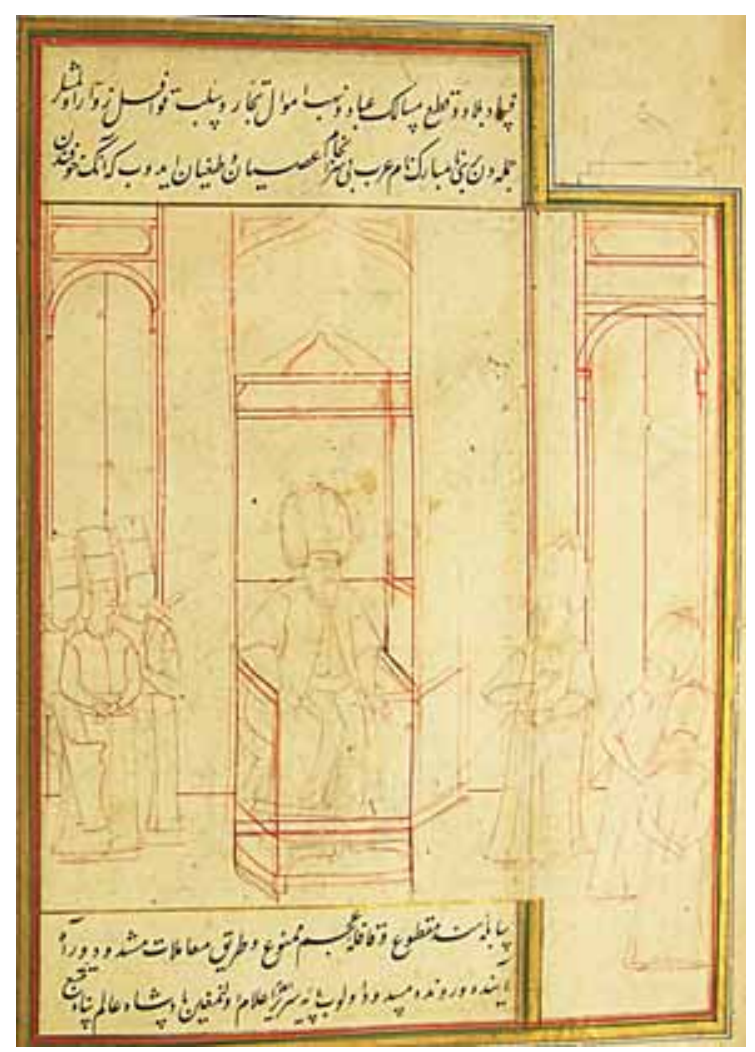

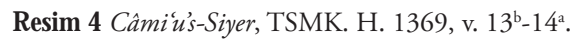

odak noktası Eğri seferidir ki yazının girişinde de belirtildiği gibi Hasan Paşa’nın bu seferin en önemli safhası olan Haçova savaşındaki rolü oldukça önemlidir. ${ }^{46}$ Bu kısa Osmanlı tarihi bölümünün sonunda III. Mehmed'in Arap eyaletlerindeki eşkıyalık hareketlerini bastırmak üzere Hasan Paşa’yı Bağdat valisi olarak görevlendirmesi; ilk önce bu görevi kabul etmek istemeyen Paşa’nın sonunda razı gelmesi anlatılır. Bu bölümü resimleyen ikinci tasvirde -ki bu da yarım kalmış resimlerden biridir- bu an, yani III. Mehmed'in Hasan Paşa'yı görevlendirmesi betimlenir. Resimde III. Mehmed tahtında oturur, arkasında yine has oda ağaları yer alır. Huzurundaki saraylılardan sultana yakın olanı Hasan Paşa olmalıdır. Bir önceki resimde figürlerin yüzleri yapılmamışken burada tasvir tamamen eskiz olarak kalmış, boyanmamıştır (Resim 4). 


\section{Sonuç}

Câmi üs'S-Siyer'in giriş bölümünün hem metin hem tasvir bağlamında vurgusuna baktığımızda, Sokullu ailesinin Osmanlı saray politikalarındaki etkin rolünün vurgulandığı görülür. Bir başka söyleyişle, Osmanlı sultanlarına ayrılmış bu bölümlerde bir nevi Sokullu ailesinin tarihi yazılmıştır. Tasvirlerde de metin bölümünün vurgusuna uygun olarak hem Sokullu hem de Hasan Paşa’nın üstlendikleri bu siyasi rolü padişahtan meşru bir şekilde almaları vurgulanmıştır. $\mathrm{Bu}$ ikonografi, Hasan Paşa'nın bir devlet adamı olarak Osmanlı siyasasında oynadığ1 role ve oluşturduğu imgeye yakışmaktadır. Zira, yukarda da değinildiği gibi Sokullu'nun oğlu olmak, Hasan Paşa’nın yöneticilik imgesini oluşturmasında oldukça etkiliydi. Hatta sonrasında Paşa’nın halk muhayyilesinde şehzadelik iddialarında bulunduğu söylentilerinin oluşmasında da hanedanlıkla soy bakımından ilişkilendirilmesi neden olmuştu. Tüm bunlar Câmi ửs-Siyer'in giriş bölümünün vurgusunun bilinçli bir tercih olduğunu gösterir; Hasan Paşa, Sokullu gibi Osmanlı politikalarının en önemli aktörlerinden birinin oğlu olduğunu öne çıkarır. Bu tutum Hasan Paşa’nın icadı değildir kuşkusuz; Osmanlı sarayında resimli kitap hamiliğinin ne kadar işlevsel bir politik araç olabileceğini ona gösteren eşsiz bir modele sahipti. Bu kişi babası Sokullu Mehmed Paşa'dan başkası değildi.

Sokullu Mehmed Paşa Osmanlı sarayındaki hamilik biçimi ile de oğlunu etkilemiş olmalıydı. Nitekim bu yazının başında da değinildiği üzere, Sokullu Mehmed Paşa'nın resimli kitap hamiliği üzerine yapılan çalışmalarda, hazırlanmasına katkı sağladığı kitaplarla --özellikle II. Selim devrinde-- kendisini adeta sultanın gerisindeki gölge güç olarak sunduğu, devlet işleyişindeki hayati rolünü bu kitapların hem metninde hem de tasvirlerinde belirgin bir şekilde vurguladığı görülür. Bu imgeyi güçlü bir şekilde öne çıkaran kitapların başında gelen Nüzhet-i esrârü̈lahyâr der-abbâr-ı sefer-i Sigetvar' 1 himayesindeki Nişancı Ahmed Feridun Bey'e yazdırması, Hasan Paşa’nın da Bağdat valisi iken hizmetinde bulunan Muhammed Tâhir el-Sıddîkî el-Necibî el-Sühreverdîye etrafındaki devlet adamlarının okuyup tartışmaları için yeni bir eser yazdırmasını hatırlatır. Hasan Paşa da tıpkı babası gibi yazdırdığı bu eserin girişine kendi aile tarihini ve bu ailenin Osmanlı siyasetinde oynadığı hayati rolü öne çıkarmıştır. Bu bölüme eşlik eden tasvirlerde de hem babasın hem de kendini sultan huzurunda tasvir ettirerek, hanedanla olan bağlarını vurgulamıştır. Ancak Hasan Paşa’nın babasından farkları da vardır; mesela tüm bunları İstanbul'da değil Bağdat'ta gerçekleştirmiştir. Bir Osmanlı tarihi yazdırmak yerine, bir İslam tarihi içine kendi kişisel tarihini ekletmiştir. 
Daha önce de değinildiği gibi, Bağdat görevi öncesi aslında Hasan Paşa’nın isteği İstanbul'da kalmak, hatta sadrazam olmaktır. Ancak bu dileği gerçekleşmemiş ve zorunlu geldiği Bağdat'ta aslında şehrin olanaklarını, hafızasını, kültürel ve tarihsel mirasını kendi yöneticilik emelleri için başarılı bir şekilde kullanmıştır.

Hasan Paşa İslamiyet'in erken döneminde gelişen olayları içeren genel bir tarih kitabı yazdırmakla birlikte eserde esas olarak Abbasi dönemi detayları ile anlatılır. Peki Hasan Paşa’nın bu tercihi sıradan bir seçim midir? Yöneticisi olduğu şehrin kurucusu olan Abbasiler'in tarihini öne çıkaran bir kitap yazdırması; dahası Abbasiler'e ve çağdaşı hanedanlıklara ayrılan altıncı defterin ardından gelecek olan ancak tamamlanamayan hatime bölümüne kendi askeri başarılarını yazdırmayı planlaması, sadece bir rastlantı mıdır? Belki de Hasan Paşa, yazdırdığı ve resimlettirdiği Câmi üs-Siyer ile kendini şehrin kadim tarihinin son yöneticisi olarak sunmak istemişti. Yani, bir bakıma bu eser kendi kişisel tarihi ile şehrin kadim tarihi arasında kurulan bir bağdı. Bu önermenin haklılık payını güçlendiren bazı emareler Hasan Paşa’nın kamusal imgesini oluşturma yolunda kullandığı araçların da ilginç bir şekilde Abbasi halifelerini akla getirmesiyle güçlenir.

Tarihçi Peçevînnin Hasan Paşa’yla ilgili söylediklerine tekrar dönersek, kendine özgü desenleri olan görkemli kıyafetleri, bu giysileriyle debdebe içinde Cuma namazına gitmesi, etrafında dolaşan yardımcılarına kendi kıyafetlerinin benzerini giydirmesi ve de üzeri çeşit çeşit meyve ve yapraklarla bezeli gümüşten bir taht yaptırması gibi garip ve görülmedik davranışların hepsini Hasan Paşa Bağdat valiliği esnasında sergilemiştir. Peçevî tüm bu davranışları öylesine şaşkınlıkla anlatmaktadır ki, benzerinin hiç bir kimsede görülmediğini özellikle belirtmektedir. Kuşkusuz Hasan Paşa’nın başkentten uzaklığı ona bu tür gösterişli ve padişahane tavırlar geliştirmesinde kısmen de olsa bir rahatık sağlamış olmalıdır. Ancak, Hasan Paşa’nın sahip olduğu gücü ve siyasi iddiasını sunmak için kullandığı araçların ilginç bir şekilde Abbasi halifelerinin görkemli yaşam biçimlerini anımsatması da onun bulunduğu şehrin köklü geçmişine ilgisiz kalmadığını, kamusal imgesini oluştururken bu geçmişten beslendiğini düşündürür.

Abbasi halifelerinin giydiği görkemli saray kıyafetleri Ortaçağ kaynaklarında büyük bir övgü ile anlatılan konuların başında geliyordu. Hem halifeler hem de Abbasi soyluları ipekten altın işlemeli lüks giysilere olan meraklarıyla bilinmekteydi. Halifelerin ve Abbasi elitinin giysileri tıpkı diğer İslam çevrelerinde olduğu gibi sıkı sıkıya kurallarla belirlenmiş kodlara sahipti. Sarayın şaşasını sunmada son derece işlevsel bir role sahip bu giysilerin kullanımı önceden belirlenmiş kurallara 
bağlıydı; mesela özel törenlerde Hz. Muhammed'e ait olduğuna inanılan kıyafetin giyilmesi, kemer ve kılıcın kuşanılması bu kurallardan biriydi. Halife Mansur (öl. 775) döneminde ise bütün devlet erkanının siyah giyinmesi zorunluluk haline getirilmişti; halifeler devlet törenlerinde siyah giysilerle katılmaya başlamıştı. Törenler dışında, özel anlarda da son derece görkemli giysiler içinde dolaşıyordu Abbasi halifeleri. Halife Mutasım'ın (öl. 842) çevgan oynamaya giderken figürlü ipek kumaştan giydiği yelek kaynaklarda bahsi geçen detaylardand1. ${ }^{47}$

Sadece kıymetli ve gösterişli kıyafetler değil, son derece değerli malzemelerle bezenmiş lüks eşyalar ve mekân düzenlemeleri de Abbasi saraylarının şaşaasını yansıtırdı. Ortaçağın önemli kaynaklarından Taberi Tarihinnde ve de Binbir Gece Masallarında Abbasi saraylarının görkemli saray bahçelerinin tasviri sıklıkla karşımıza çıkar. Mesela, Halife Harun Reşid'in, Bağdat'ta Dicle boyunca kurdurduğu el-Huld Sarayı'nın bahçe düzenlemeleri dönem şairlerine ilham kaynağı olmuştur. Anlatılanlara göre, Sasani ve Emevi bahçelerinden esinlenen bu cennet bahçelerinde altın ve gümüş yapraklı ağaçlar, etraflarında süs olarak kıymetli maden ve taşlar, küçük dereler, fiskiyeler, havuzlar, suların üzerinden geçen köprüler yer alırdı. Tamamen insan eliyle düzenlenmiş bu bahçelerin ortasında yer alan sarayda halife ipek ve kadifelerle kaplı, altın ve değerli taşlarla bezeli tahtı üzerinde otururdu. ${ }^{48}$

Tüm bunlar Hasan Paşa’nın gösteriş ve görkemle hemhal olmuş imgesinin oluşumunda Abbasi geleneklerinin ilham verici olduğunu düşünmemize yol açmaktadır. Giysi ve davranışlar dışında Paşa’nın kendisi için yaptırdığı müzeyyen tahtı sadece Abbasi halifelerinin görkemli eşyalarını hatırlatmakla kalmıyor; bir Osmanlı yöneticisinin cüretkar tavrını da yansıtıyordu. Nitekim, bu taht, Hasan Paşa'nın sadece gösterişe olan tutkusunu yansıtmaz, 'saltanata' olan merakının ve de hevesinin de en bariz göstergesidir. Peçevînnin Kâh-ı Beheşt adı verilen bu tahtın Celali eşkıyasının eline geçtiğini anlattığı bölümde tahttan, ikinci defada Ravza'-i Beheşt, yani 'Cennet Bahçesi' olarak bahsetmesi, bu tahtın tek başına olmadığını, tıpkı Abbasi halifelerinin yapay bahçe düzenlemeleri gibi bir bahçe düzenlemesinin parçası olabileceğini akla getirir ki, eğer öyleyse Hasan Paşa’nın Bağdat üzerinden Abbasi tarihi ve halifeleri ile kurduğu bağ daha da güçlü bir

47 Muhammad Manazir Ahsan, Social Life under the Abbasids 170-289 AH/786-902 AD (London and New York: Longman, 1979), s. 51-52.

48 André Clot, Harun al-Rashid and the World of the Thousand and One Nights, çev. John Howe, (London: Saqi Books, 1989), s. 40. 
olasılık haline gelir. Tıpkı 18. yüzyıldaki, saltanatı çevreleyen Osmanlı elitinin alışkanlıklarının gösteriş̧̧i bir tüketim kültüründen ziyade saltanatla kurdukları ortaklığın bir meşruiyet aracı olması gibi, Hasan Paşa da daha 16. yüzyıl sonlarında benzer araçları kendi siyasi iddiasını meşrulaştırmak için kullanmış gibi görünmektedir. Bu kullanımda, bir yandan Osmanlı sarayının geleneksel hamilik biçimlerini sürdürürken diğer yandan da içinde bulunduğu yeni çevrenin, yani Bağdat şehrinin, sunduğu olanakları ustalıkla kendi amaçlarına uyarlamıştır. Bu uyarlama, merkez-taşra bağlamında Osmanlı elitinin/bürokratlarının oluşturdukları kültürel çevreyi ve bu çevrenin maddi kültürdeki yansımalarını sorgulamak için de yeni kapılar aralayacak niteliktedir ki bu sorular halihazırda meraklılarını beklemektedir.

Bir Osmanl Paşasının Padişahlık Rüyası: Sokulluzâde Hasan Paşa ve Resimli Dünya Tarihi

Öz - Osmanlı sarayında, hanedan ve hanedan mensupları için hazırlanan resimli kitaplar sadece edebi bir zevkin ya da lüks tüketim kültürünün birer aracı olmamıştır. Bu eserler aynı zamanda iktidar arenasındaki karmaşık himaye ilişkilerinin, bu ilişkilerin kahramanları olan farklı hizip ve aktörlerin siyasi alandaki çekişmelerinin bir aracı olarak kullanılmıştır. Bu makalede resimli bir elyazmasından yola çıkılarak şu sorulara yanıt aranacaktır: Resimli elyazması hamiliği politik propagandanın aracı olarak nasıl kullanılıyordu? Hamisinin siyasi iddia ve dertleri resimli bir elyazmasının metnine ve tasvirlerinin ikonografisine ne şekilde yansıyordu? Bir başka söyleyişle, erken modern Osmanlı saray çevresinde güç sembolleri görsel ve yazılı kültürde ne şekilde görünür kılınıyordu? Daha genel bağlamda ise, Osmanlı eliti olmanın maddi kültür boyutu nelerdi? Tüm bu sorulara cevap aramak için Sokulluzâde Hasan Paşa için Bağdat valiliği sırasında hazırlanan musavver Câmiüs-Siyer (TSMK, H. 1369 ve H. 1230) adlı dünya tarihi kullanılacaktır. Bu örnekten yola çıkılarak Hasan Paşa’nın gösterişli/gösterişçi davranışları ve bu davranışların siyasi iddiaları ile olan bağlantısı irdelenecektir. Bu sorgulama Osmanlı elitinin kamusal imajını yaratırken kullandığı araçların maddi kültür alanındaki yansımalarını anlamayı da kolaylaştıracaktır.

Anahtar kelimeler: Câmi ü̉s-Siyer, Hasan Paşa, Bağdat, Resimli elyazmaları, Maddi kültür 


\section{Kaynaklar}

\section{Birincil Kaynaklar}

Feridun: Nüzhet-i Esrârül-Ahyâr Der-Abbâr-1 Sefer-i Sigetvar: Sultan Süleyman’n Son Seferi, haz. A. Arslantürk, Günhan Börekçi, Abdülkadir Özcan, İstanbul: Zeytinburnu Belediyesi 2012.

Kınalızâde Ali Çelebi: Ablâk-ı Alầ, haz. Mustafa Koç, İstanbul: Klasik Yayınları 2007.

Koçi Bey: Koçi Bey Risaleleleri, haz. Seda Çakmakoğlu, İstanbul: Kabalıı Yayınları 2007.

Mecmua, Bibliothèque nationale de France, Paris, Turc 140.

Muhammed Tâhir el-Sıddîkî el-Necibî el-Sühreverdî: Câmi üs-Siyer, TSMK. H. 1369 ve 1230.

Mustafa b. Molla Rıdvan el-Bağdadi: Târîh-i Fetihnâme-i Bağdâd, Oxford Bodleian Library, Or. 276.

Nâdirî: Dîvân-ı Nâdirî, TSMK, H. 889.

Naîmâ Mustafa Efendi: Târih-i Naî̀mâ, (Ravzatül-Hüseyn fî Hulâsati Ahbâri'l-Hâfikayn) I-IV, haz. Mehmet İpşirli, Ankara: Türk Tarih Kurumu Yayınları 2007.

Nazmi-zâde Murteza: Gülşen-i Hulefâ. Bă̆dat Tarihi 762-1717, haz. Mehmet Karataş, Ankara: Türk Tarih Kurumu 2014.

Peçevî: Târîh-i Peçevî, 2. cilt, Matbaa-i Amire 1283.

Selânikî Mustafa Efendi: Tarih-i Selânikî (971-1003/1563-1595), I-II, haz. Mehmet İpşirli, Ankara: Türk Tarih Kurumu Yayınları 1999.

\section{Yayınlar}

Afyoncu, Erhan: "Sokulluzade Hasan Paşa", Türkiye Diyanet Vakfı İslâm Ansiklopedisi, 37 (2006), s. 366-368.

Ahsan, Muhammad Manazir: Social L:ife under the Abbasids 170-289 AH/786-902 AD, London and New York: Longman 1979.

Argıt, Betül İ.: "An Evaluation of the Tulip Period and the Period of Selim III in the Light of Clothing Regulations", Osmanl Arasstrrmalar/The Journal of Ottoman Studies, XXIV (2004), s. 11-28.

Artan, Tülay: "18. yüzyıl başlarında yönetici elitin saltanatın meşruiyet arayışlarına katılımı”, Toplum ve Bilim, 83 (Kış 1999), s. 292-321.

Bağcı, Serpil: “Seyyid Battal Gazi Türbesi’nin Gümüş Kapısı Üzerine Bazı Gözlemler,” Dokuzunси Milletlerarası Türk Sanatları Kongresi, Bidiriler, Cilt I, Ankara: Kültür Bakanlığı Yayınları 1995 , s. 225-238.

Bağc1, Serpil: “Adem'den III. Mehmed'e: Silsilenâme”, Padişahın Portresi: Tesavir-i Âl-i Osman, İstanbul: Türkiye İş Bankası Kültür Yayınları 2000, s. 188-201.

Bağcı, Serpil vd.: Osmanlı Resim Sanatı, İstanbul: Kültür Bakanlığı Yayınları 2006.

Börekçi, Günhan: Factions and Favorites at the Courts of Sultan Ahmed I (r. 1603-17) and his Immediate Predecessors, (Yayımlanmamış Doktora Tezi), Ohio: Ohio State University, 2010.

Casale, Giancarlo: The Ottoman Age of Exploration, New York and Oxford: Oxford University Press, 2010. 


\section{TÜLÜN DEĞİRMENCİ}

Clot, André: Harun al-Rashid and the World of the Thousand and One Nights, çev. John Howe, London: Saqi Books 1989.

Çağman, Filiz: "XVI. Yüzyıl Sonlarında Mevlevi Dergahlarında Gelişen Bir Minyatür Okulu”, I. Milletlerarası Türkoloji Kongresi, 3. Türk Sanatı Tarihi, İstanbul 1979, s. 651-677.

Değirmenci, Tülün: İktidar Oyunlart ve Resimli Kitaplar: II. Osman Devrinde Değiş̧en Gü̧̧ Simgeleri, İstanbul: Kitap Yayınevi 2012

Değirmenci, Tülün: "An Illustrated Mecmua: The Commoners Voice and the Iconography of the Court in Seventeenth-Century Ottoman Painting," Ars Orientalis, 41 (December 2011), s. $186-218$.

Durı, A. A.: "Baghdād", The Encyclopedia of Islam (New Edition), I (Leiden 1986), s. 894-908.

Emecen, Feridun M.: "Osmanlı Hanedanına Alternatif Arayışlar Üzerine Bazı Örnekler ve Mülahazalar," İlàm Araștırmaları Dergisi (Turkish Journal of Islamic Studies) 6 (2001), s. 63-76.

Fetvacı, Emine: Sarayın İmgeleri, Osmanlı Sarayının Gözüyle Resimli Tarih, çev. Nurettin Elhüseyni, İstanbul: Yapı Kredi Yayınları 2013.

Fleischer, Cornell H.: Bureaucrat and Intellectual in the Ottoman Empire: The Historian Mustafa Âli (1541-1600), Princeton: Princeton University Press 1986.

Griswold, William J.: Anadolu’da Büyük İsyan, 1591-1611, çev. Ülkü Tansel, İstanbul: Tarih Vakfı Yurt Yayınları 2002.

Hathaway, Jane: The Politics of Households in Ottoman Egypt: The Rise of the Qazdağlis New York: Cambridge University Press 1997.

Hathaway, Jane: A Tale of Two Factions: Myth, Memory, and Identity in Ottoman Egypt and Yemen, Albany, NY: State University of New York, 2003.

Kunt, İ. Metin: "Ethnic- Regional (Cins) Solidarity in the Seventeenth-Century Ottoman Establishment," International Journal of Middle East Studies, 5 (1974), s. 233-239.

Kunt, İ. Metin: Sultan's Servants: The Transformation of Ottoman Provincial Government, 15501650, Colombia: Colombia University Press 1983.

Milstein, Rachel: Miniature Painting in Ottoman Baghdad, Costa Mesa CA 1990.

Murphey, Rhoads: "Forms of Differentiation and Expression of Individuality in Ottoman Society", Turcica, 34 (2002), s. 135-170.

Önal, Ahmet: Koca Sinan Paşa’nın Hayatı ve Siyasi Faaliyetleri 1520-1596 (Doktora tezi), İstanbul: Marmara Üniversitesi, 2012.

Özgen, Elif: Grand Vizier Koca Sinan Paha and Factional Politics in the Court of Murad III, (Yayımlanmamış Yüksek Lisans Tezi), İstanbul: Bilgi Üniversitesi, 2010.

Öngören, R.: "Sühreverdî, Ebü’n-Necîb”, Türkiye Diyanet Vakfı İslâm Ansiklopedisi, 38 (2010), s. 35-36.

Peirce, Leslie: The Imperial Harem: Women and Sovereignty in the Ottoman Empire, Oxford: Oxford University Press 1993.

Reindl-Kiel, Hedda: Leisure, Pleasure - and Duty. The daily life of Silahdar Mustafa, éminence grise in the final years of Murad IV (1635-1640), Berlin: EB-Verlag, 2016. 
Schmidt, Jan: Pure Water for Thirsty Muslims: A Study of Mustafā Älì of Gallipoli’s Künhü l-Abbār, Leiden: The Oosters Instituut 1991.

Schmidt, Jan: Catalogue of Turkish Manuscripts in the Library of Leiden University and other Collections in the Netherlands, I, Leiden: Legatum Warneriaum 2000.

Strange, Guy le: Baghdad during the Abbasid Caliphate from Contemporary Arabic and Persian Sources, Westport: Greenwood Press 1977.

Taner, Melis: Caught in a Whirlwind: Painting in Baghdad in the Late Sixteenth-Early Seventeenth Centuries (Doktora Tezi), Cambridge, MA: Harvard University, 2016.

Tezcan, Baki: "Ethnicity, Race, Religion and Social Class: Ottoman Markers of Difference", The Ottoman World, ed. Chrisitine Woodhead, New York: Routledge 2012, s. 159-170.

Tezcan, Baki: Searching for Osman: A Reassessment of the Deposition of the Ottoman Sultan Osman II (1618-1622), (Yayınlanmamış Doktora Tezi), Princeton: Princeton University, 2001.

Tezcan, Baki: The Second Ottoman Empire: Political and Social Transformation in the Early Modern World, New York: Cambridge University Press 2010.

Unan, Fahri: İdeal Cemiyet, İdeal Devlet, İdeal Hükümdar, Ankara: Lotus Yayınları 2004.

Ünver, Süheyl: "XVII inci Yüzyıl Sonunda Padişaha bir Lâhiya”, Belleten, XXXIII (1969), s. 21-24.

Quinn, Sholeh A: Historical Writing during the Reign of Shah Abbas: Ideology, Imitation, and Legitimacy in Safavid Chronicles, Salt Lake City: The University of Utah Press 2000.

Yeşil, Fatih: "How to be(come) an Ottoman at the End of the Eighteenth Century", Osmanlı Araşttrmalarl The Journal of Ottoman Studies, XLIV (2014), s. 123-139. 